\title{
Future upstream water consumption and its impact on downstream water availability in the transboundary Indus Basin
}

\author{
Wouter J. Smolenaars ${ }^{1}$, Sanita Dhaubanjar ${ }^{2,3}$, Muhammad K. Jamil ${ }^{1,4}$, Arthur Lutz ${ }^{2}$, Walter Immerzeel ${ }^{2}$, \\ Fulco Ludwig ${ }^{1}$, and Hester Biemans ${ }^{1,5}$ \\ ${ }^{1}$ Water Systems and Global Change Group, Wageningen University, Wageningen, 6708 PB, the Netherlands \\ ${ }^{2}$ Department of Physical Geography, Utrecht University, Utrecht, 3584 CB, the Netherlands \\ ${ }^{3}$ International Centre for Integrated Mountain Development, Kathmandu, 44700, Nepal \\ ${ }^{4}$ Pakistan Agricultural Research Council, Islamabad, 44690, Pakistan \\ ${ }^{5}$ Water and Food Research Group, Wageningen Environmental Research, Wageningen, the Netherlands
}

Correspondence: Wouter J. Smolenaars (wouter.smolenaars@wur.nl)

Received: 27 July 2021 - Discussion started: 2 August 2021

Revised: 17 December 2021 - Accepted: 17 January 2022 - Published: 17 February 2022

\begin{abstract}
The densely populated plains of the lower Indus Basin largely depend on water resources originating in the mountains of the transboundary upper Indus Basin. Recent studies have improved our understanding of this upstreamdownstream linkage and the impact of climate change. However, water use in the mountainous part of the Indus and its hydropolitical implications have been largely ignored. This study quantifies the comparative impact of upper Indus water usage, through space and time, on downstream water availability under future climate change and socio-economic development. Future water consumption and relative pressure on water resources will vary greatly across seasons and between the various sub-basins of the upper Indus. During the dry season, the share of surface water required within the upper Indus is high and increasing, and in some transboundary sub-basins future water requirements exceed availability during the critical winter months. In turn this drives spatiotemporal hotspots to emerge in the lower Indus where seasonal water availability is reduced by over $25 \%$ compared to natural conditions. This will play an important, but previously unaccounted for, compounding role in the steep decline of per capita seasonal water availability in the lower Indus in the future, alongside downstream population growth. Increasing consumption in the upper Indus may thus locally lead to water scarcity issues, and increasingly be a driver of downstream water stress during the dry season. Our quantified perspective on the evolving upstream-downstream linkages in the transboundary Indus Basin highlights that long-
\end{abstract}

term shared water management here must account for rapid socio-economic change in the upper Indus and anticipate increasing competition between upstream and downstream riparian states.

\section{Introduction}

The Indus Basin is shared by Pakistan, India, Afghanistan and China, and is home to over 260 million people (Wada et al., 2019). The basin is among the most depleted and water stressed in the world (Laghari et al., 2012; Wada et al., 2011). The arid plains of the lower Indus Basin are densely populated and rely on the largest contiguous irrigation system in the world for their food production. Water demands for irrigation - but also increasingly for domestic and industrial purposes - considerably exceed the dry season supply of freshwater and are compensated for by the overexploitation of groundwater resources (Karimi et al., 2013; Wijngaard et al., 2018). Despite the current overuse of water resources, progress towards achieving the interlinked food and water security Sustainable Development Goals (SDGs 2 and 6 respectively) in the Indus Basin is insufficient ( $\mathrm{Ra}$ sul, 2014, 2016). Moreover, the direct and indirect water resources required to meet these SDGs are projected to increase further under pressure from socio-economic development (Smolenaars et al., 2021; Vinca et al., 2020). Achieving and sustaining the food and water security SDGs in the 
transboundary Indus Basin can only succeed with basin-wide integrated adaptation efforts (Immerzeel and Bierkens, 2012; Immerzeel et al., 2020).

Over $85 \%$ of the Indus Basin's annual discharge originates from the mountainous and scarcely populated upper Indus (Biemans et al., 2019), which is shared between all four riparian states. A combination of snowmelt and monsoon rainfall causes mountain water availability across the basin to surge over the Asian summer, while run-off during the dry winter is limited (Laghari et al., 2012). The vast irrigation networks and megacities of the Pakistani and Indian lower Indus Plains are therefore highly dependent on the timely provision of mountain water resources (Biemans et al., 2019; Flörke et al., 2018; Wijngaard et al., 2018), a considerable part of which is transboundary in origin. Previous modelling studies showed that climatic and socio-economic changes may intensify existing Indus Basin upstream-downstream dependencies. Climate change is projected to cause a consistent rise and seasonal shift in upper Indus run-off (Lutz et al., 2014), while population growth, economic progress and urbanization are likely to spur rapid growth of downstream water demands (Biemans et al., 2013; Wijngaard et al., 2018).

Consequently, the Indus Basin has been framed as containing strong, one-directional upstream-downstream linkages; the mountainous upper Indus provides water and the populous plains of the lower Indus consume it (Khan et al., 2020; Laghari et al., 2012; Reggiani and Rientjes, 2015; Wijngaard et al., 2018). Research investigating the future water resources of the upper Indus Basin has accordingly remained largely within the bio-physical domain, only exploring the effects of climate change on upstream hydrology and its role as source of water (Khan et al., 2020; Lutz et al., 2014, 2016a; Reggiani and Rientjes, 2015). Regional modelling studies on the influence of anthropogenic activities on the Indus Basin water system have likewise focused on the lower Indus Basin (Momblanch et al., 2019; Vinca et al., 2020; Wada et al., 2019; Yang et al., 2016), or simply assumed upstream water-use activities to be insignificant (Biemans et al., 2019; Wijngaard et al., 2018). Only Amin et al. (2018) and Mehboob and Kim (2021) explicitly examined the development of water demands in the upper Indus Basin. But these studies only covered the upstream parts of the Pakistani share of the basin and did not quantify downstream or cross-border implications.

However, rapid socio-economic development is not limited only to the lower Indus Basin. The upper Indus Basin also contains fast emerging urban centres (Kabul, Jalalabad, Peshawar, Srinagar; see Fig. 1) that will place an increasing claim on water resources in the future (Smolenaars et al., 2021). Upstream anthropogenic activities can exacerbate, or even cause, downstream hydrological droughts (Rangecroft et al., 2019; Van Loon et al., 2016), especially in basins like the Indus, where downstream areas rely heavily on water generated by upstream sources (Zhou et al., 2019). Already at present, transboundary water allocation issues in the Indus
Basin are exacerbating and causing considerable geopolitical tension in the water stressed Kabul sub-basin between upstream areas in Afghanistan and downstream areas in Pakistan (Atef et al., 2019). Global assessments of upstreamdownstream linkages in transboundary basins that quantified future dependencies (Munia et al., 2018; Viviroli et al., 2020) and drivers of water stress (Degefu et al., 2019; Munia et al., 2016, 2020) similarly found the Indus Basin at considerable risk for future conflicts. Such studies are however based on coarse approaches that aggregate the basin into upstream, midstream and downstream units, and provide limited quantitative insight at the level of individual Indus tributaries where transboundary issues, as seen in the Kabul subbasin, arise in practice. Socio-economic changes in the upper Indus will thus increasingly affect water availability in both the upper and lower Indus Basin and water sharing between riparian states, but the potential magnitude of their influence throughout the basin is presently unclear.

Transboundary water management and adaptation in the context of the SDGs requires a spatially explicit understanding of the interplay between future water demands and availability, and between upstream and downstream regions (Rangecroft et al., 2019; Yillia, 2016). Additional disaggregated insight into the implications of changing water-use activities in the upper Indus on water availability throughout the Indus Basin, particularly in relation to climatic changes, is therefore needed. In this study we hypothesize that water consumption in the upper Indus can no longer be ignored, and that it will be an increasingly important driver of transboundary downstream water stress in the coming century. The aim of this paper is to quantify, both in space and time, the potential impact of upper Indus water consumption on lower Indus water availability, accounting for both socio-economic development and climate change. To do so, validated datasets on Indus hydrology and socio-economic development are combined within a novel water accounting approach that conceptually simulates the complex upstreamdownstream dependencies in the transboundary Indus Basin. The results provide the first quantified perspective on the comparative role of upper Indus socio-economic changes within the broader development of Indus Basin upstreamdownstream linkages. This insight is important for long-term shared water management between riparian states, adaptation research and hydrological modelling at the basin and sub-basin scales. The approach presents a novel way forward for regionalized upstream-downstream assessments in other complex transboundary river basins. 


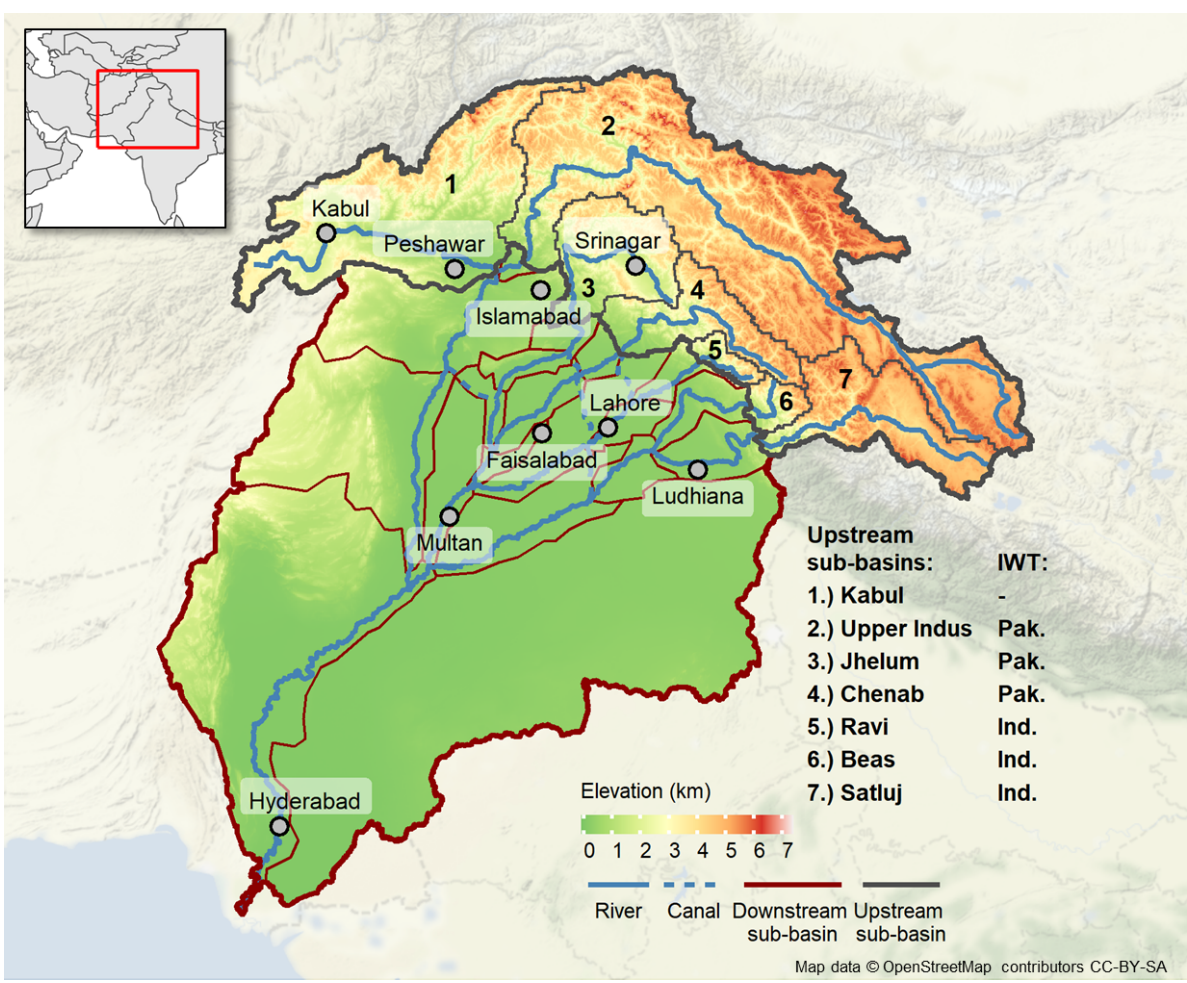

Figure 1. Elevation map of the Indus Basin with delineation of upper (numbered) and lower Indus sub-basins, and the allotment of Indus tributaries between India and Pakistan according to the Indus Water Treaty (IWT). () OpenStreetMap contributors 2022. Distributed under the Open Data Commons Open Database License (ODbL) v1.0.

\section{Methods and materials}

\subsection{Case study description: state of water management in the Indus Basin}

Since ancient times, the water resources of the Indus River and its tributaries have been used extensively for irrigation practices in the fertile lower Indus Plains. The current Indus Basin Irrigation System (or IBIS) was first developed around the 1850 s and gradually expanded over many decades to become the largest continuous irrigation system in the world. After the Partition in 1947, the IBIS, and the upstream areas that provide it with vital water resources, were divided between India and Pakistan. This major change in riparian relations within the Indus Basin led to a highly complex transboundary water management setting (Zawahri and Michel, 2018). In a bid to improve shared water management, the World Bank brokered the Indus Water Treaty (IWT) between India and Pakistan in 1960 (Qamar et al., 2019).

The IWT allocates the water resources of the upper Indus between two riparian states (see Fig. 1), with Pakistan receiving control over the water of the western tributaries (Indus, Jhelum and Chenab), and India over that of the eastern tributaries (Ravi, Beas and Satluj - also spelt Sutlej; Miner et al., 2009). While this allots a majority of Indus water system discharge to Pakistan (Kalair et al., 2019), the three western tributaries originate in or cross the Indian share of the basin before feeding into the lower Indus in Pakistan. The IWT therefore allows limited local water use (e.g. irrigation and domestic purposes) and unlimited non-consumptive use (e.g. run-of-river hydropower and transportation) in upstream India in these tributaries (Zawahri and Michel, 2018). Although the IWT has facilitated three notable transboundary water conflicts and regulated hydropolitical relations for more than 6 decades, many have pointed out the need to update the framework to meet new challenges imposed by global change (Parvaiz, 2021; Qamar et al., 2019).

The IWT is not the only treaty governing water management and distribution in the Indus Basin. In Pakistan, the Indus water system is the sole source of fresh surface water for the large majority of the country. Water allocation between the provinces of Pakistan is consequently arranged via the Pakistan Water Appointment Accord, which distributes available flow roughly by order of water demand over the four Pakistani provinces (Basharat, 2019). This framework has been shown to work well in high-flow periods, but intranational disputes have occurred in years of drought, with downstream regions claiming to receive consistently less water than what should be allotted to them (Hassan et al., 2019). Other regions of the Indus Basin are not governed by transboundary treaties. The most prominent of these is the Kabul River basin, one of the largest tributaries of the Indus River 
and a major source of fresh water for both Pakistan and Afghanistan (Qamar et al., 2019). Similarly, upstream China is not part of any water sharing agreement in the Indus Basin, but its claim on water resources has so far remained limited due to the low population density and mountainous terrain of its share of the basin (Zawahri and Michel, 2018).

In this study, we used the context of the IWT and shared water management in the Indus Basin, as described here, to shape our water accounting approach - both in terms of spatial resolution and in terms of the water-use sectors that we consider. In addition, we reflect on the implications that our results may hold for this shared water management context in the discussion section.

\subsection{Upstream-downstream water accounting approach}

To quantify the impact of upper Indus water usage on downstream water availability we used a water accounting approach at the sub-basin level of individual Indus tributaries, and at seasonal timescale. We applied this approach to assess future changes for two integrated climatic and socioeconomic change scenarios over the period 1980-2080. For both scenarios, our approach consisted of two assessment steps. First, we quantified the development of upper Indus water availability under climate change and subtracted future water consumption. Then, we allocated remaining upstream water over downstream sub-basins and assessed downstream water availability, with and without accounting for upstream consumption. The distribution of remaining water from upstream sub-basins over their respective downstream sub-basins was determined using a novel upstream-todownstream allocation algorithm developed in this study (see Fig. 2 and Sect. 2.5.3). Water availability in our approach is operationalized as the per capita available water resources in $\mathrm{m}^{3} \mathrm{yr}^{-1}$, as this accounts for the effect of population changes on the relative water resources available for socio-economic activities (Hanasaki et al., 2018). In the following sections we explain in more detail the spatiotemporal resolution and methods that comprise our approach, and the scenarios and data we used to apply it to our Indus Basin assessment.

\subsection{Spatial and temporal disaggregation}

\subsubsection{Sub-basin delineation}

Previous studies that quantified transboundary upstreamdownstream linkages (Degefu et al., 2019; Munia et al., $2016,2018,2020$ ) used approaches that divide river basins into two or three sub-basins with a linear flow of water between them. Similarly, our study was also conducted at the sub-basin level. However, instead of assessing the entire upper Indus as one lumped sub-basin, our approach defined sub-basins for each of the main tributaries subject to the IWT (see Fig. 1 and Sect. 2.1) and the Kabul River. Subbasins (see Fig. 1) were delineated using a pour point analy- sis in ESRI ArcGIS with a 5 arcmin drainage direction map from HydroSHEDS (Lehner et al., 2006). First, the upper Indus sub-basins were established by determining the upstream area of the Indus River and its main tributaries. For each river course, the cut-off between upstream and downstream was set at major dams situated within the mountain-to-plain transition zone, which is an often used definition in Indus Basin hydrology (Lutz et al., 2014, 2016a; Wijngaard et al., 2018). The contributing area upstream from these locations were assessed and resulted in seven sub-basins that were named after their respective main river (see Fig. 1).

To facilitate the spatially explicit assessment of downstream impacts due to upper Indus water use, the connectivity between the lower Indus and the upper Indus sub-basins needed to be established. Similar to our upstream delineation of sub-basins, we disaggregated the lower Indus Basin into multiple sub-basins, based on the overlapping downstream areas of upper Indus sub-basins. Specifically, we delineated lower Indus sub-basins at the confluences of rivers originating from the upper Indus Basin. These sub-basins are thus defined by the upper Indus tributaries they receive water from. This allowed our approach to assess which areas within the lower Indus are particularly affected by upstream consumption, whereas above-mentioned lumped approaches only provided insight into the upstream-downstream linkage of the basin at large. The distribution of mountain water throughout the lower Indus Basin is however highly controlled by an expansive system of barrages and linkage channels (Wescoat et al., 2018). This infrastructure plays a key role in Indus Basin water management as it allows riparian states to optimally distribute their scarce water resources (Basharat, 2019). The water flows through the most important linking canals (Indus-Jhelum, Jhelum-Chenab-RaviSatluj and Chenab-Ravi; see Fig. 1) were therefore also considered in the delineation of downstream sub-basins and the designation of the downstream area of the upper Indus subbasins. This approach resulted in 18 lower Indus sub-basins that each receive water resources from a unique combination of upper Indus sub-basins (see Fig. 1).

\subsubsection{Seasonality and timeframe}

The strong seasonal character of Indus hydrology requires water resource assessments to be conducted at the seasonal level (Laghari et al., 2012). Therefore, contrary to the annual level of previous studies (Munia et al., 2016, 2018, 2020; Viviroli et al., 2020), we aggregated and analysed hydrological changes and impacts for the two hydrological seasons suggested by Laghari et al. (2012), which correspond to the main agricultural season: the Dry season (Rabi cropping season, November-April) and the Wet season (Kharif cropping season, May-October). Additionally, for some analyses the seasons were disaggregated further into the four climatological seasons used in other regional water system studies (Rajbhandari et al., 2015; Wijngaard et al., 2018): 

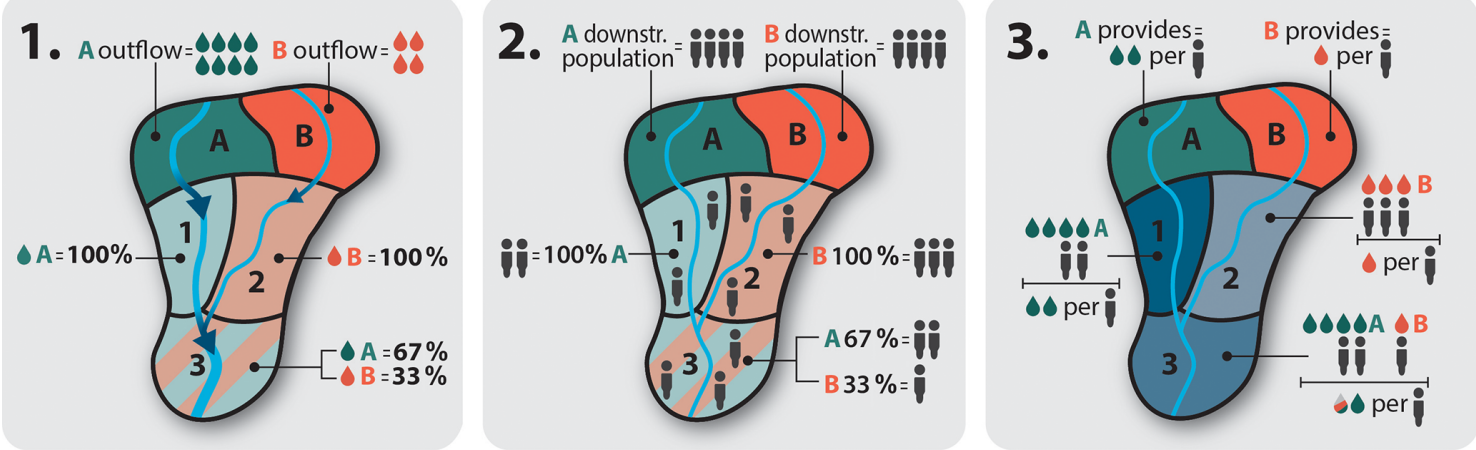

Figure 2. Conceptual representation of the allocation of upstream sub-basin water resources to downstream sub-basins. First, (1) the relative contribution of each upstream sub-basin to the total upstream inflow of each downstream sub-basin is determined. Next, (2) the population of each downstream sub-basin is determined and assigned to the upstream sub-basins by their relative flow contribution. Lastly, (3) upstream outflows are divided by their total assigned downstream populations to obtain the per capita upstream water availability they provide to the downstream sub-basins. The upstream per capita water availability per downstream sub-basin is the mean per capita availability provided by all contributing upstream basins, weighted by their assigned populations. The total per capita water availability of a downstream sub-basin is determined by aggregating the local downstream per capita water availability and the upstream per capita water availability.

Pre-monsoon (March-May), Monsoon (June-August), Postmonsoon (September-November) and Winter (DecemberFebruary). To illustrate the progression of water consumption and availability over time, data were assessed as transient annual time series or for three assessment time steps: the 1980-2010 historical reference period (Ref) and the future 2030-2050 (Mid) and 2060-2080 (Late) periods.

\subsection{Integrated scenarios}

Both climate and socio-economic changes might increase pressure on available water resources. To obtain insight into potential future changes in upstream-downstream linkages and impacts, we defined two regional scenarios that integrate socio-economic development and climate change. The socio-economic core of the scenarios was sourced from a set of regionalized and spatially downscaled Shared Socioeconomic Pathways ("SSPs"; see O'Neill et al., 2014) specifically downscaled towards 2080 for the Indus Basin by Smolenaars et al. (2021). The optimistic "SSP1-Prosperous" (sustainable economic progress and low population growth; hereafter, SSP1) and the pessimistic "SSP3-Downhill" (fragmented economic stagnation and high population growth; hereafter, SSP3) storylines were selected, as these provided the highest contrast and thus the broadest plausible bandwidth of results.

The socio-economic storylines are regionally downscaled extensions of the global SSP storylines and can therefore be consistently matched with the Representative Concentration Pathway (RCP) emissions framework (van Vuuren et al., 2014). To represent future climatic conditions we expanded the SSP1 and SSP3 storylines with respectively the moderate RCP4.5 and extreme RCP8.5 emission trajectories. This resulted in two future scenarios for climate, population and
GDP: SSP1-RCP4.5 and SSP3-RCP8.5 (hereafter referred to by their contextual storyline as SSP1 and SSP3).

\subsection{Upstream-downstream assessment and data sources}

\subsubsection{Scenario forcing data}

Applying the two integrated scenarios within our quantitative upstream-downstream approach required us to obtain spatially explicit climatic and socio-economic forcing data for our scenarios (see Table 1). For the socio-economic storylines, there are downscaled GDP projections in addition to spatially explicit future population projections towards 2080 at $5 \operatorname{arcmin}(\sim 8 \mathrm{~km})$ resolution that account for population growth and urbanization (Smolenaars et al., 2021). For the 1980-2010 reference period, we used the 5 arcmin population maps of the HYDE project (Klein Goldewijk et al., 2011). Historical GDP data were obtained from Institute for Applied Systems Analysis (IIASA; Dellink et al., 2017). Climate change projections at a daily timescale for the coupled $\mathrm{RCP}$ emission scenarios were obtained from eight (four per $\mathrm{RCP}$ ) downscaled general circulation model (GCM) projections for the wider South Asia region at 5 arcmin resolution over the period 1980-2100 (Lutz et al., 2016b).

\subsubsection{Determining the impact of upper Indus water consumption on remaining water availability}

As the first assessment step of our approach, we determined for both scenarios the progression of water consumption in the upper Indus Basin in relation to the change in water availability under socio-economic development and climate change. For the upper Indus sub-basins, daily natural discharges were determined at the sub-basin outlets (i.e. the 
Table 1. Input datasets used for water accounting analysis.

\begin{tabular}{|c|c|c|}
\hline Input dataset & $\begin{array}{l}\text { Resolution } \\
\text { (time/space) }\end{array}$ & Source \\
\hline \multicolumn{3}{|l|}{ Discharge } \\
\hline Upper Indus & $\begin{array}{l}\text { Daily } 1980-2100 / \\
\text { sub-basin outlets }\end{array}$ & Wijngaard et al. (2017) \\
\hline Lower Indus & $\begin{array}{l}\text { Daily } 1980-2080 / \\
5 \text { arcmin }\end{array}$ & $\begin{array}{l}\text { Simulated by this study; model and calibration from Bondeau et al. (2007) } \\
\text { and Biemans et al. (2016) }\end{array}$ \\
\hline \multicolumn{3}{|l|}{ Consumption } \\
\hline Domestic & $\begin{array}{l}\text { Annual 1980-2080/ } \\
\text { national level }\end{array}$ & Simulated by this study; model and calibration from Bijl et al. (2016) \\
\hline Industrial & $\begin{array}{l}\text { Annual 1980-2080/ } \\
\text { national level }\end{array}$ & Simulated by this study; model and calibration from Bijl et al. (2016) \\
\hline Agricultural & $\begin{array}{l}\text { Monthly 1980-2080/ } \\
5 \text { arcmin }\end{array}$ & $\begin{array}{l}\text { Simulated by this study; model and calibration from Bondeau et al. (2007) } \\
\text { and Biemans et al. (2016) }\end{array}$ \\
\hline \multicolumn{3}{|l|}{ Scenarios } \\
\hline Population projections & $\begin{array}{l}\text { Annual 1980-2080/ } \\
5 \text { arcmin }\end{array}$ & $\begin{array}{l}\text { Smolenaars et al. (2021) for future (2015-2080) and Klein Goldewijk et al. } \\
\text { (2011) for historical (1980-2015) }\end{array}$ \\
\hline GDP projections & $\begin{array}{l}\text { Annual 1980-2080/ } \\
\text { national level }\end{array}$ & $\begin{array}{l}\text { Future (2015-2080) Smolenaars et al. (2021) and historical (1980-2015) } \\
\text { Dellink et al. (2017) }\end{array}$ \\
\hline Climate data & $\begin{array}{l}\text { Daily } 1980-2100 / \\
5 \text { arcmin }\end{array}$ & Lutz et al. (2016b) \\
\hline
\end{tabular}

absolute surface water availability per sub-basin). Validated high-resolution discharge projections for the seven upper Indus sub-basins were used at daily time steps for the reference period and for both RCP scenarios (1980-2100; Wijngaard et al., 2018, 2017). These projections are generated by the distributed Spatial Processes in Hydrology (SPHY) cryosphere-hydrology model based on the same downscaled climate forcing data that pertain to the climatic scenarios of this study. The SPHY model was developed specifically to simulate the glacier-dominated hydrology of High Mountain Asia and has been often been applied to the Indus Basin (Biemans et al., 2019; Lutz et al., 2014, 2019).

Subsequently, we decreased the daily natural discharges with daily aggregated consumptive water requirements for the domestic, industrial and agricultural sector of each subbasin to estimate actual discharge. Consumptive water requirements were defined as the sectoral water demands, minus the return flows (Bijl et al., 2016), which represent the amount of natural water resources made unavailable for downstream usage. Consumptive water requirements in excess of daily surface water availability were assumed to be stored within the sub-basin in the closest preceding days to the surplus discharge and released on the day the shortages occurred. The difference between natural and actual outflow of upper Indus sub-basins therefore always equalled the con- sumptive requirements at the annual level, but for daily time steps these occasionally varied. Sectoral consumption data were obtained from the following sources.

- Domestic and industrial consumptive water requirements projections for the upper Indus Basin were obtained with the regression models of Bijl et al. (2016). The models simulate annual water consumption intensity per sectoral unit (capita and USD of GDP respectively) as a product of economic development (expressed in GDP per capita) increasing efficiency through time, and a pre-calibrated "region factor" that accounts for climatological and cultural circumstances (see Appendix A). The models were forced for each basin country with the national-level GDP per capita projections of the scenario forcing data. As the Bijl models provided an annual consumption value, daily consumptions were assumed to be $1 / 365$ th of the annual output and thus to not vary within the projected year. The simulated daily consumption intensities were multiplied by the projected total population and GDP of the basin share of each country, and then spatially distributed over the gridded population projections of the scenarios. Population data for both the reference and projected periods was available at 10 -year time steps in the forcing dataset. To obtain annual values, the data 
were linearly interpolated between these time steps. Lastly, the gridded consumption data were summed for each upper Indus sub-basin.

- To obtain water usage data for the agricultural sector the grid-based integrated crop production-hydrology Lund-Potsdam-Jena managed Land (LPJmL) model was used. LPJmL simulates water balance and crop production for 12 crops (irrigated and rainfed), and the interaction between them, whilst considering climatic circumstances and anthropogenic interventions (Bondeau et al., 2007). This allows the influence of crop production on the water system to be quantitatively untangled and studied under climatic and socio-economic changes (Gerten et al., 2011; Rost et al., 2008). For this study a regional LPJmL version was used that was developed specifically to represent the monsoon-dominated double-cropping systems of South Asia at 5 arcmin resolution (see Biemans et al., 2019). The South Asia LPJmL version has been applied to multiple integrated assessments that include the Indus Basin (Biemans et al., 2019; Wijngaard et al., 2018), and its agricultural water withdrawals have been validated for the broader South Asia region (Biemans et al., 2016, 2013). The LPJmL simulations were conducted with unlimited groundwater access for irrigation, providing an estimate of the potential agricultural water consumption. This avoids inconsistencies with the discharge data obtained from the SPHY model. LPJmL was forced with the downscaled climate data pertaining to the scenario dataset and with regional land use based on land-use change projections for SSP1 and SSP3 from the IMAGE integrated assessment model (Stehfest et al., 2014). The land-use projections were constructed at 5 arcmin resolution by applying the IMAGE growth-rates for rainfed and irrigated crops to 2005 land-use extents from the spatially explicit MIRCA-2000 dataset (Portmann et al., 2010), an approach that is often used for scenariobased studies with LPJmL (Wijngaard et al., 2018). The daily consumptive water requirements were determined by aggregating the blue water consumption (i.e. evapotranspiration originating from blue water (surface and groundwater) resources) of agriculture from evapotranspiration and conveyance losses and summing these for each sub-basin. Surface water in LPJmL is only extracted if there is a soil moisture deficit. This agricultural green water footprint (i.e. evapotranspiration originating from green water (precipitation) resources) was not considered in the total agricultural water usage, as the SPHY discharge projections already account for green water evapotranspiration through a natural vegetation layer (Wijngaard et al., 2017).

To further interpret the consequences of climatic and socioeconomic changes on the status of water availability in the upper Indus Basin, the availability per capita (APC) index
(Hanasaki et al., 2018), which is an expanded version of the well-known Falkenmark index (Falkenmark et al., 1989), was applied. The APC index assesses the annual available water resources per capita and categorizes these by the degree to which water scarcity is limiting a society:

- No water stress: $>5000 \mathrm{~m}^{3}$ per capita per year

- Low water stress: 5000-1700 $\mathrm{m}^{3}$ per capita per year

- Moderate water stress: $1700-1000 \mathrm{~m}^{3}$ per capita per year

- High water stress: $1000-500 \mathrm{~m}^{3}$ per capita per year

- Extreme water stress: $<500 \mathrm{~m}^{3}$ per capita per year

Lastly, the impact of upper Indus consumption on environmental flows was studied using the variable monthly flow (VMF) method as applied by Pastor et al. (2019). VMF holds that a minimum of respectively $30 \%$ and $60 \%$ of mean natural flows in the dry and wet seasons must be maintained for environmental well-being. Thus, only $70 \%$ and $40 \%$ of water resources during the wet and dry season can sustainably be consumed (Pastor et al., 2014). Minimum daily flow thresholds were determined for the mean daily flows over the historical reference period (1980-2010) and the wet and dry season definition by Laghari et al. (2012). The status of environmental flows was expressed as the days per year in which minimum flows are not met at the outlet of upper Indus subbasins.

\subsubsection{Quantifying upstream-downstream linkages and impacts}

For the second assessment step of our approach we quantified the impact of upper Indus consumption on water availability in the lower Indus. This step required surplus water resources in the upper Indus sub-basins to be allocated over the lower Indus sub-basins. Previous studies (Degefu et al., 2019; Munia et al., 2016, 2018, 2020) used a linear method for this upstream-to-downstream water allocation, meaning that surplus water flows from an upstream sub-basin to one fixed downstream sub-basin. However, our water accounting approach considered multiple upstream sub-basins, with an overlapping mesh of downstream sub-basins. We moreover accounted for linkage channels (see Sect. 2.3.1) when defining the downstream area of each upper Indus sub-basin. This means that the downstream distribution of surplus upstream water is not only based on natural flow direction, but it is also demand based and thereby inherently variable. The abovementioned linear methods were thus not suitable to simulate upstream-to-downstream water allocation in our regionalized approach.

We therefore developed a new routine (see Fig. 2) that works similar to the approach of Viviroli et al. (2020), which distributes surplus upstream water resources equally over all 
downstream grid cells. Instead of distributing surplus upstream water on the basis of geographical area, however, we distributed it based on population, as we think this is a better proxy for where water demand is located. Our upstreamdownstream water allocation algorithm assumes an equitable distribution of upper Indus outflows among the downstream population of each upper Indus sub-basin. Populations of lower Indus sub-basins that are downstream from multiple upper Indus sub-basins were divided and assigned to upstream sub-basins relative to the water supplied (see Fig. 2). This allowed for the simultaneously allocation of upstreamdownstream water resources for all upper Indus sub-basins, without having to make quantitative assumptions as to how water is distributed between multiple competing downstream sub-basins.

We applied this upstream-to-downstream allocation routine for the three assessment time steps (Ref, Mid and Late). First, the average natural flow and average actual flow were determined per season and then distributed over the lower Indus sub-basins. The allocation procedure used the spatially explicit population projections of the scenario forcing data set as population input data for the lower Indus sub-basins. The total water availability of each lower Indus sub-basin was then determined by aggregating, for each time step and season, the allocated upper Indus water resources with average water supply generated within the lower Indus sub-basin itself. Here, it was assumed that all water resources generated in a lower Indus sub-basin are utilized within that sub-basin. The water resources originating locally in the lower Indus sub-basins were determined with the LPJmL model. Simulations were run with naturalized upstream inflow, natural vegetation and without anthropogenic water withdrawals, an approach that is often used to determine natural flows (Jägermeyr et al., 2017; Rost et al., 2008). The model was forced with the downscaled climate data of the respective scenarios. For each of the lower Indus sub-basins, the discharges at its outlet were assessed and the inflows from outside the sub-basins were extracted (i.e. the discharges at the outlets of sub-basins directly feeding into a sub-basin), thus leaving only the water generated within the sub-basin itself.

The impact of upper Indus consumption on lower Indus water availability was then studied by comparing relative differences in total seasonal water availability between the actual and natural flow conditions for each time step. As availability between seasons and sub-basins varied greatly, the absolute and annual-based APC index was not suitable for this analysis. Water availability in the future time steps was additionally compared to reference period availability to assess the change in lower Indus water availability through time under integrated climate change and socio-economic development. This provided insight into the comparative role of upper Indus water consumption. Similarly, per capita water availability in the lower Indus in our approach was also affected by population growth, and by climate change through its effect on discharges. We therefore additionally assessed water availability in the lower Indus sub-basins for future time steps with downstream population distributions and climatic conditions independently kept at reference period conditions (i.e. with population maps and discharges as they were in the Ref 1980-2010 time step). This allowed for the isolated effects of climate change and downstream population changes on future water availability in the lower Indus to be quantified and compared to the impact of upper Indus consumption.

\section{Results}

\subsection{Changes in upper Indus water consumption}

Figure $3 \mathrm{~b}$ shows that the reference period total water consumption in the upper Indus Basin is around $6.9 \mathrm{~km}^{3} \mathrm{yr}^{-1}$ (compared to approximately $140 \mathrm{~km}^{3} \mathrm{yr}^{-1}$ in the lower Indus Basin, Wijngaard et al., 2018). Water-use activities are mostly located in the Kabul, Indus and Jhelum sub-basins and are dominated by agricultural water use during the wet season. The population in the upper Indus is projected to grow by $124 \%$ and $245 \%$ towards 2080 in SSP1 and SSP3 respectively (Table 2, compared to reference period 19802010). The highest population growth will be in the Kabul sub-basin (188\% in SSP1 and $350 \%$ in SSP3), especially in the Afghani share (Smolenaars et al., 2021). This sub-basin contains three large cities, two of which are in Afghanistan, projected to expand rapidly following strong urbanization trends (see Fig. 3a). Water consumption in the upper Indus subsequently demonstrates annual growth of $13 \mathrm{~km}^{3} \mathrm{yr}^{-1}$ (88\%, SSP1) and $17 \mathrm{~km}^{3} \mathrm{yr}^{-1}(146 \%$, SSP3) in the 20602080 period. Consumption increases are largely concentrated in sub-basins that already account for the majority of present water usage. The Kabul and Jhelum sub-basins are projected to face annual water-use increases of respectively as much as $135 \%$ and $307 \%$ in the SSP3 Late period, with this growth largely located in the respective Afghani and Indian parts.

The projected growth in water consumption is highest for the domestic sector (Fig. 3b). Population growth and economic progress are projected to increase both the number of end-users and the amount of consumed water resources per end-user. Economic growth similarly drives an increase in the industrial water use. Agricultural water use only increases slightly from present-day values as expansion options in the mountainous upper Indus are limited and higher temperatures due to climate change reduce the length of the growing season of staple crops (Wijngaard et al., 2018). The relative growth in the domestic and industrial water-usedominated dry season (179\% in SSP1 and $296 \%$ in SSP3) is therefore greater than in the wet season $(60 \%$ in SSP1 and $102 \%$ in SSP3) and the annual average (see Figs. A1 and A3). Figure 3 shows that the seasonal difference in water consumption in the upper Indus Basin is accordingly projected to decrease by the Late period in both scenarios. 


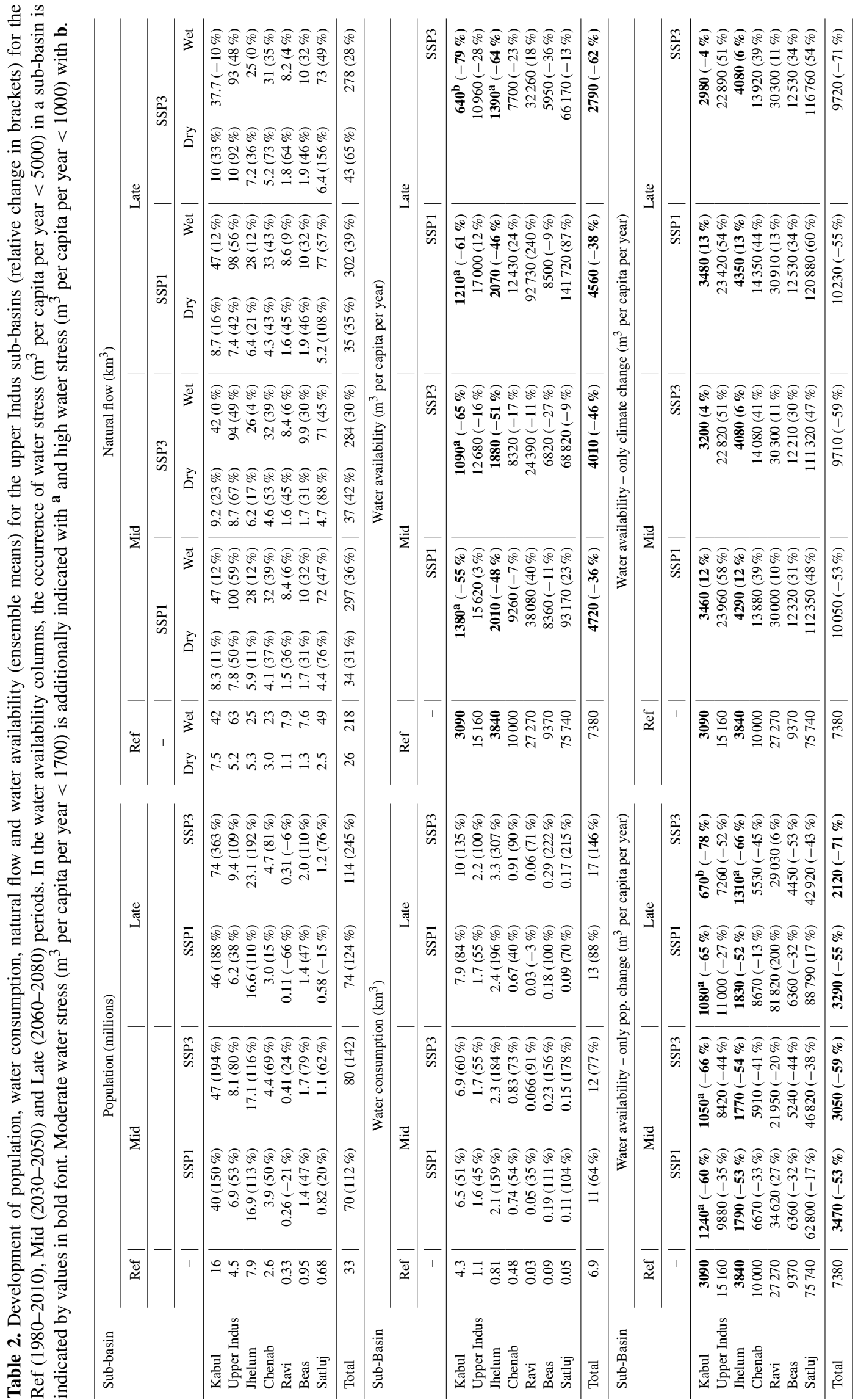



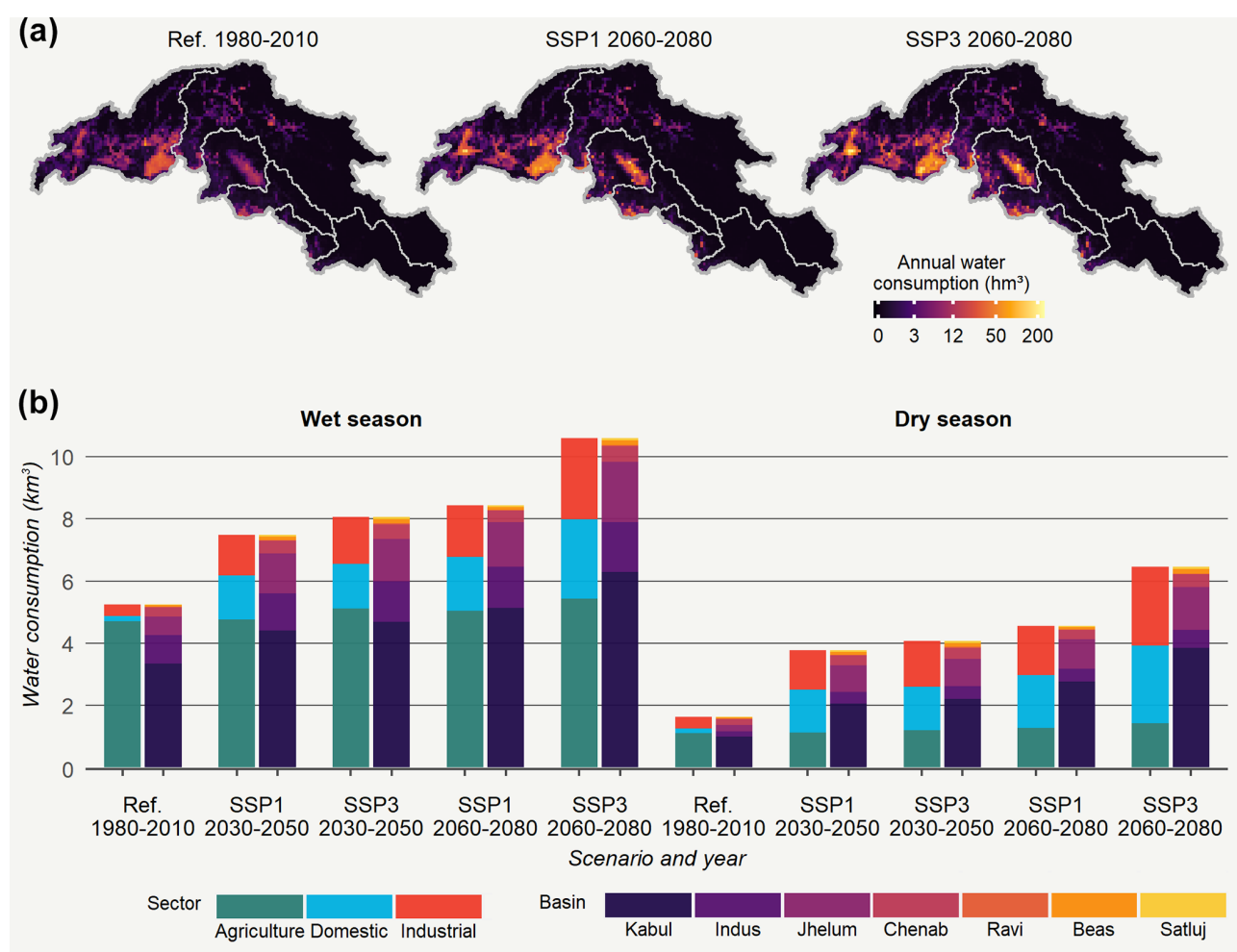

Figure 3. Spatially (a), seasonally and sectoral (b) disaggregated water consumption in the sub-basins of the upper Indus Basin. Agricultural water use is based on the ensemble mean. The total height of the bars (b) indicates total water use in the upper Indus.

\subsection{Impact of climatic and socio-economic changes on upper Indus water resources}

Table 2 demonstrates that the ensemble mean annual flow of the upper Indus increases by $38 \%$ and $32 \%$ respectively in the SSP1 and SSP3 scenarios for the 2060-2080 period. The heightened discharge is consistent between the two scenarios, as both predict temperatures in South Asia to increase $\left(\sim 2{ }^{\circ} \mathrm{C}\right.$ in RCP4.5 and $\sim 5^{\circ} \mathrm{C}$ in RCP8.5; see Lutz et al., 2016b), which drives increased glacial melting until at least the end of the century (Wijngaard et al., 2017). The relative increase is most pronounced in the dry season. The development of discharge does nonetheless vary greatly between the sub-basins. The Satluj and Indus sub-basins are projected to face annual flow increases of up to $54 \%$ and $51 \%$ respectively, while those of the Kabul and Jhelum sub-basins stay roughly similar over the projected period.

Despite the general increase in surface water availability, the mean annual per capita water availability in the upper Indus Basin is projected to drop by $43 \%$ (SSP1) and $65 \%$ (SSP3) by the Late period under pressure from rapid population growth (Table 2). The application of the APC index in Table 2 illustrates that the upper Indus Basin as a whole is projected to drop from a "no water stress" situation in the reference period to a "low water stress" situation in the Mid period of both scenarios. However, the per capita water availability change is highly heterogenous between the subbasins. In the reference period the relatively densely populated and transboundary Kabul and Jhelum sub-basins fall into the low water stress category of the APC index and are projected to move into the "high" and "moderate" water stress categories in the Late period of the SSP3 scenario, largely due to rapid population growth surrounding major urban centres in the Afghani and Indian shares of the respective basins (Smolenaars et al., 2021). In contrast, other subbasins, such as Satluj, Chenab and Ravi, all located largely in India, remain firmly in the no water stress category and even face a net increase in per capita water availability in the SSP1 scenario due to the positive effect of climate change on discharges here.

Figure $4 \mathrm{~b}$ demonstrates that during the reference period the consumed share of total annual surface water resources is negligible at about $2 \%$. Because of the seasonal discharge patterns, the consumption in the driest (winter) period of the year does exceed $10 \%$ of total discharge (Fig. 4a). Despite rapid population growth, the share of total annual water resources consumed in the upper Indus Basin only increases to $4.1 \%$ and $5.5 \%$ in SSP1 and SSP3 respectively in the Late period (see Fig. A1). However, on average, the consumed basin-level fraction reaches a considerable $15 \%$ (SSP1) and $18 \%$ (SSP3) over the entire dry season and exceeds $30 \%$ during the December and January months. Corresponding 
to the pace of population growth, the development of relative water consumption differs between sub-basins. In the Kabul sub-basin, consumptive needs during the Late period in the driest months of the year exceed $80 \%$ of available surface water on average and even fully surpass it in low discharge years. In the SSP3 scenarios, the consumed share during the wet season also reaches a considerable $17 \%$ to $21 \%$ (SSP1 and SSP3 respectively). Similarly, in the Jhelum subbasin, the average consumed share over the entire dry season reaches $18 \%$ (SSP1) and $23 \%$ (SSP3) in the Late period and consumptive needs during the winter months may exceed discharges in the driest years. Sub-basins with positive discharge changes due to climate change and low population growth, such as Satluj, remain virtually unaffected in both scenarios.

The rapid increase in consumptive water needs relative to water availability during the dry season is projected to affect environmental flows in the Kabul and Jhelum upper Indus sub-basins. Figure 5 illustrates that in these basins, by 2080 on average environmental flows will not be met for roughly one-half (Kabul) and one-third of the year (Jhelum). Environmental flows also appear to gradually be affected in the Chenab and Beas sub-basins during low discharge years. On the other hand, environmental flows in the Satluj and main Indus sub-basins see very limited impact in the present and will remain largely unaffected over the course of the century. In some scenarios and time steps, the impact even decreases compared to the present. This is especially true in the Satluj sub-basin, where the increase in flow due to climate change is far larger than the increase in water consumption due to socio-economic changes (see Table 2). Environmental flows are least affected during the monsoon season.

\subsection{Future downstream water availability under socio-economic and climate change}

The influence of upper Indus consumption on the per capita water availability in the lower Indus Basin (see Appendix Fig. A4) varies greatly between the seasons. Analogous to the periods of the year in which the consumed share in the upper Indus is highest, Fig. 6 illustrates that its impact on downstream water availability is most pronounced in the winter season. During the reference period, some sub-basins in the Pakistani Punjab are already shown to be slightly affected in the order of $8 \%$ to $12 \%$, but in the Late period the available water here may decrease by more than a quarter on average. However, the impact during the post-monsoon season demonstrates the most considerable rise. Several Pakistani sub-basins shift from being largely unaffected during the reference period to facing mean water availability reductions of $14 \%$ (SSP1) and $20 \%$ (SSP3) in the Late period. The influence on water availability during the monsoon season doubles in most basins, but nevertheless does not exceed $6 \%$. Throughout all seasons the impact of upper Indus consumption is strongest in the sub-basins that receive their wa- ter from the Kabul and Jhelum upper Indus sub-basins. Additionally, sub-basins with limited local per capita water availability (e.g. due to high population densities or extremely arid conditions) will be more affected, as their relative dependency on mountain water resources is higher. The regional urbanization trends and subsequent spatial concentration of population magnifies this effect in several sub-basins containing large cities. The pattern of basins most affected by upstream consumption is similar between the scenarios, but the degree of impact is higher in the SSP3 scenario.

The impact of upper Indus consumption on lower Indus water availability is not an isolated process, but intertwined with climate changes and with socio-economic changes in the lower Indus itself. Table 2 and Fig. $4 \mathrm{~b}$ demonstrate that climate change causes an increase in discharge from the upper Indus Basin and for the lower Indus a slight increase in precipitation is also projected (Lutz et al., 2019). The isolated impact of climate change (Fig. 7) likewise increases Late period per capita water availability in most lower Indus sub-basins by $20 \%$ to $50 \%$ compared to reference period climatic conditions. In the areas downstream from the Beas and Satluj upstream sub-basins, largely located in the Indian Punjab and Haryana states, this increase may even exceed $50 \%$. The increase in downstream water availability from climate change outweighs the decrease due to upper Indus water use, except in the sub-basins in Pakistan that are directly downstream from the Kabul and Jhelum sub-basins during the dry season in SSP1. Figure 7 moreover demonstrates that lower Indus population growth from an average of 168 million inhabitants over the reference period to 267 million in the SSP1 Late period (see Fig. A2) causes a $20 \%$ to $50 \%$ decrease in per capita water availability of most sub-basins. Rapid population growth to 443 million inhabitants in the SSP3 scenario drives an almost universal decrease of over $60 \%$.

Accordingly, the combined impact of climate change and socio-economic development in the upper Indus largely results in a net increase in the absolute water available to lower Indus sub-basins. However, population growth in the lower Indus Basin also requires these resources to be shared among more recipients. The absolute dependency of the lower Indus Basin on water resources originating in the upper Indus Basin thereby increases. The integrated effect of these processes drives the mean per capita water availability for the majority of lower Indus sub-basins in the SSP1 Late period to decrease by $10 \%$ to $40 \%$ compared to reference period availability, with only the sub-basins in the Indian share of the basin, downstream from the Beas sub-basin, showing a slight increase (see Fig. 7). In SSP3 the integrated drivers cause a general reduction between $40 \%$ and $60 \%$. The double sided negative effects of socio-economic development on lower Indus water availability thus outpace the positive effect of climate change. 

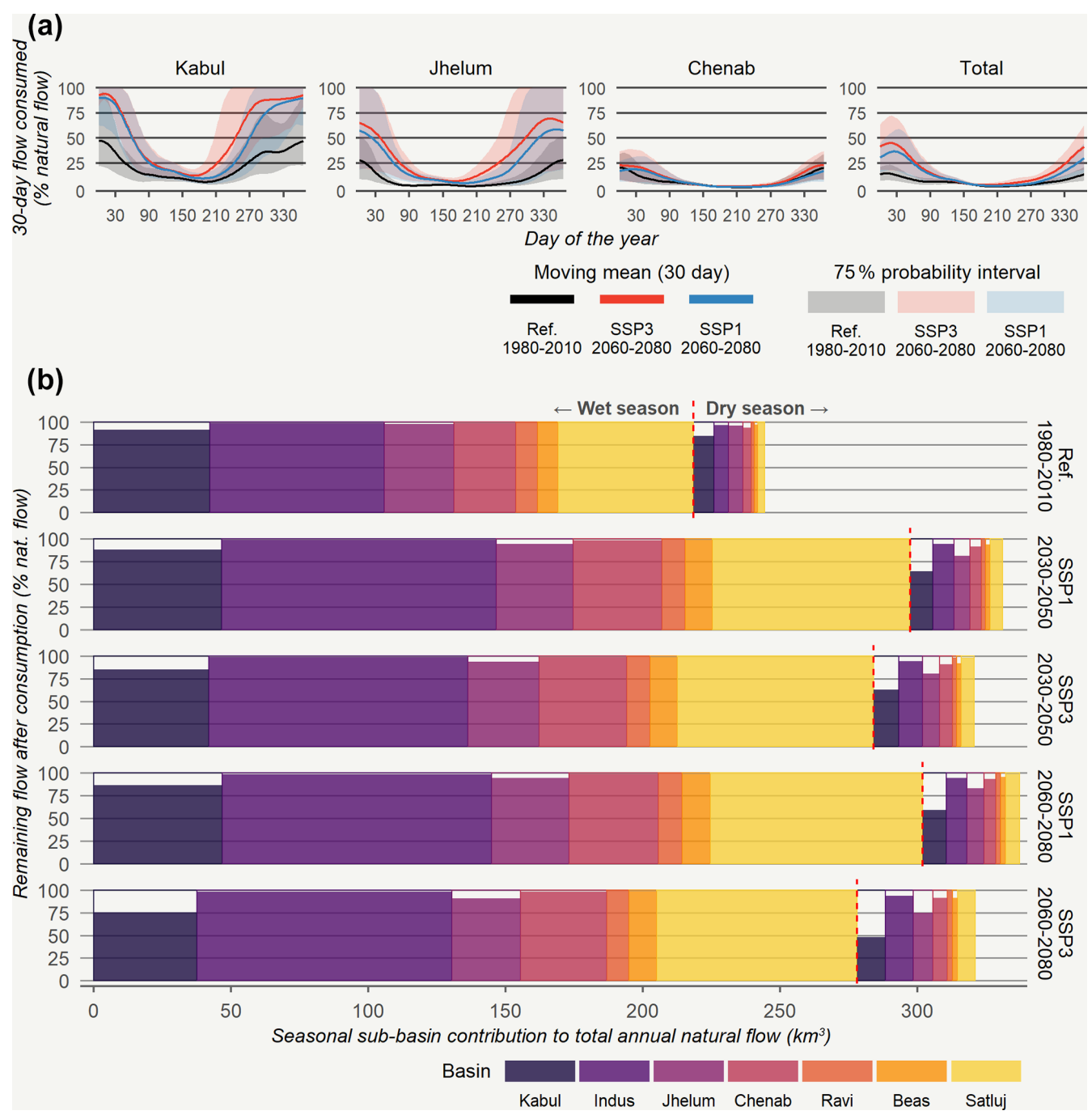

Figure 4. Daily share of natural flow consumed in the upper Indus sub-basins during the reference period and the projected Late time periods (a). Development of ensemble mean absolute upper Indus outflow under climate change and the impact of consumption (b).

\section{Discussion}

\subsection{Limitations and opportunities for future research}

This study quantified the development of water consumption in the upper Indus Basin and its effect on water availability in the lower Indus Basin. The water accounting approach that was applied to obtain these results by design is a simplified conceptual representation of the complex Indus Basin water system, as this allowed the broader patterns of upstreamdownstream dependencies to be assessed. The methodological approach influenced the quantifications presented in this study and their implications.

Primarily, upper Indus consumption was assumed to be fulfilled exclusively with surface water resources generated seasonally within the sub-basins. In reality, there may be spatial mismatches or quality-related preferences that cause part of upper Indus water demand to be fulfilled by unsustainable groundwater extraction. Groundwater reservoirs may moreover perform a modulating role between seasons, with excess surface water resources infiltrating in wet periods to be used in times when water is scarce. Around the city of Kabul, groundwater levels have however dropped considerably over the last decades (Mack et al., 2013). Similarly, on the lower Indus Plains, groundwater resources are an important supplementary source for urban and agricultural water demand (Basharat et al., 2015; Biemans et al., 2019; Wijngaard et al., 2018). But these resources are also depleting rapidly, especially in the Indian Punjab (Richey et al., 2015; Salam et al., 2020). The impact of upper Indus Basin water consumption on water availability in the lower Indus in the dry season will remain subdued while these resources are still available. This does however imply the likely aggravation of groundwater dependency and thereby overextraction. Due to a lack of spatial coverage in observational data, the availability and 

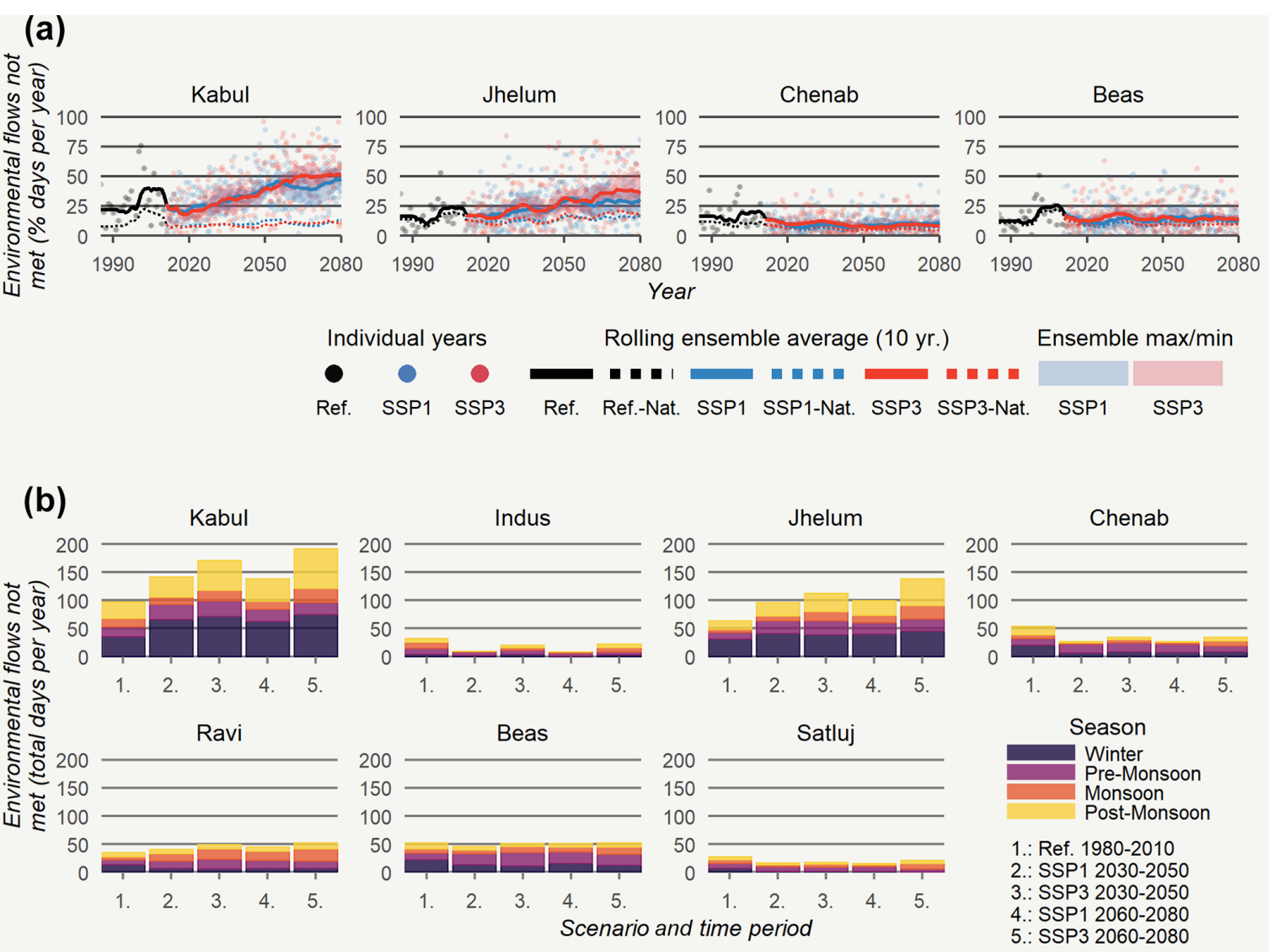

Figure 5. Impact of upper Indus consumption on environmental flows at the outlet of the upper Indus sub-basins over the assessment period (a) and per season (b).

long-term durability of groundwater resources in the upper Indus Basin remain uncertain (Cheema et al., 2014; Qureshi et al., 2010; Salam et al., 2020). More research into the status and development of groundwater here is required so that it may be considered in future research steps.

Water quality issues can similarly play an important role in upstream-downstream relations (Wolf, 2007), as exemplified by transboundary water quality disputes emerging in the Chenab and Jhelum sub-basins (Ahmad and Iqbal, 2016; Zawahri and Michel, 2018). Return flows from domestic, industrial and agricultural water usage upstream may be polluted and reduce the downstream availability of water that is of usable quality (Yoon et al., 2015). However, water stress and availability in our analysis are operationalized using indicators for water quantity and do not consider the impact of reduced water quality. The water stress experienced in the lower Indus due to expanding upstream activities may hence be higher than the reduction in availability projected in this study if pollution prevention measures are not taken. Follow-up research could expand the water accounting analysis applied in this research with water quality indicators for a more holistic assessment of future upstream-downstream linkages. Such analysis may additionally reflect on increas- ing pollution with socio-economic development and the need for pollution prevention measures to curb water stress.

In our upstream-to-downstream allocation routine, we moreover assumed upstream outflows to be distributed equitably over all downstream inhabitants. Water-use activities in the lower Indus sub-basins were thereby not considered. However, inhabitants closer to upper Indus sub-basins may consume more upstream water than their allocated share and reduce water availability further downstream. Other lower Indus sub-basins with surplus local water resources may positively affect water availability in other sub-basins. On the other hand, intra-national water sharing treaties, such as the Pakistani Water Appointment Accord, do ensure that upstream water distribution throughout the lower Indus Basin is not determined solely based on the independent self-interest of each downstream region (Hassan et al., 2019). The results of this study thus provide quantified insight into general trends of lower Indus water availability and the times and areas most likely to be affected by changing upper Indus wateruse activities from an intrinsic upstream-to-downstream perspective, instead of fully disaggregated quantifications of future water distribution in the lower Indus Basin. 

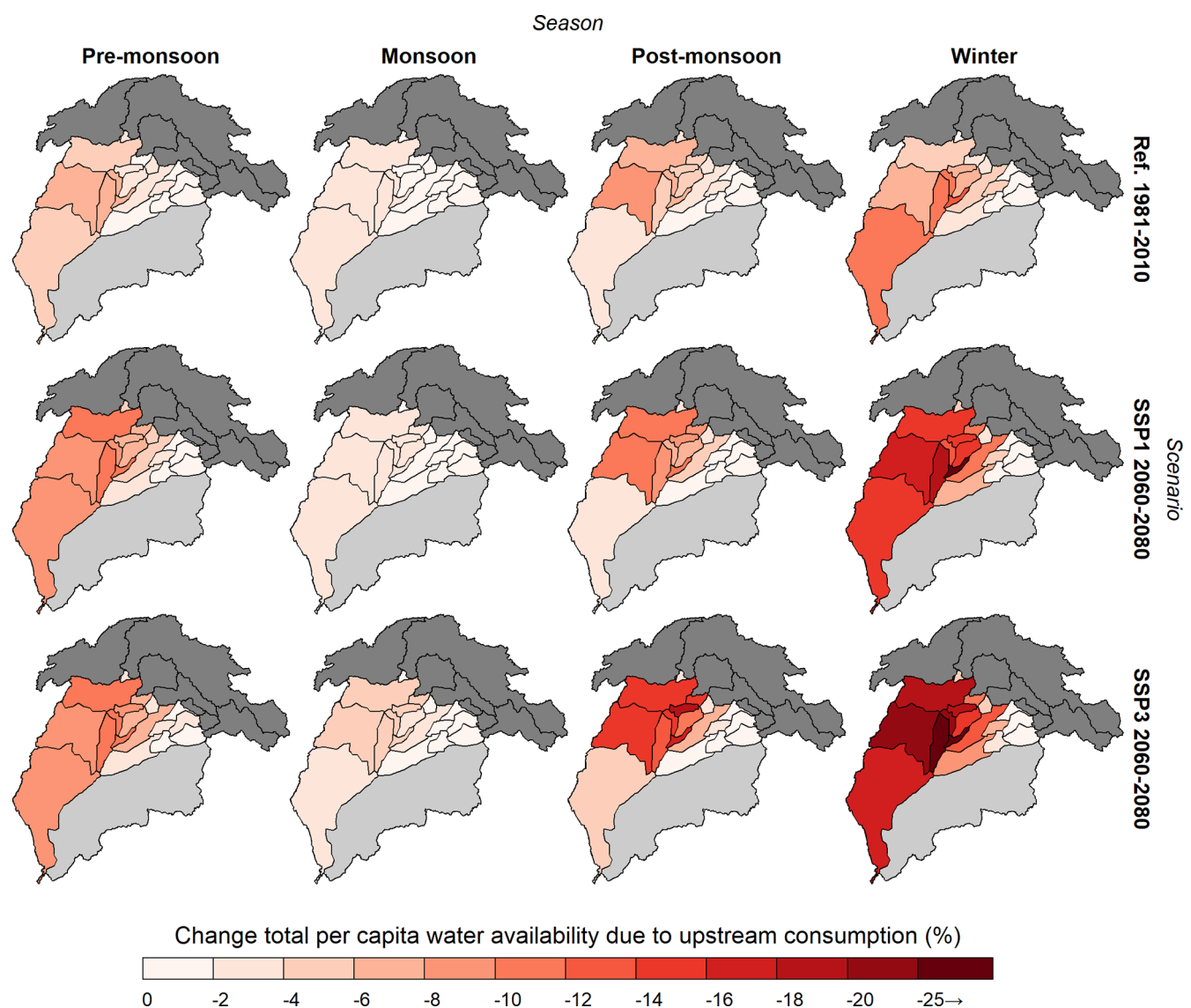

Figure 6. Seasonal mean impact of upper Indus water consumption on the water availability per capita of the lower Indus sub-basins for all years and ensemble members. The dark grey area herein represents the upper Indus sub-basins. The light grey area is not downstream of any of the upper Indus sub-basins and is therefore omitted.

High-resolution spatial information on the development of water resources is however required to support data-driven water management and adaptation policy-making to support the SDGs (Laghari et al., 2012; Rangecroft et al., 2019; Yillia, 2016). Our assessment made considerable gains in this regards compared to previous upstream-downstream studies, but further spatial disaggregation with fully distributed models and the subsequent inclusion of adaptation measures to curb water stress are important follow-up steps for robust adaptation planning. Accounting for the unique regional, often socio-economic, characteristics that govern water distribution in transboundary rivers basins is challenging in data-intensive and process-based hydrological models. In this light, our conceptual approach offers a valuable alternative to establish initial benchmarks. Our accounting routine provides disaggregated insight into potential hotspot areas and seasons for upstream-downstream impacts and their drivers, with only limited data requirements and a flexible and transparent water allocation mechanism. This approach could similarly be applied to study future upstreamdownstream linkages in other complex transboundary basins such as the Mekong and the Nile (Johnston and Smakhtin,
2014). Follow-up research could additionally perform a similar assessment to quantify hydrological interactions between sub-basins within the lower Indus. The relation between the irrigation-dominated plains of the Indus midstream and the hyper-arid delta could be of particular interest (Laghari et al., 2012). Similarly, more insight into the interplay between socio-economic and climatic drivers for future upstreamdownstream linkages in the Indus Basin is important, for example by using different, less-conventional, SSP-RCP scenario combinations.

\subsection{Implications for future transboundary water management and adaptation planning}

The quantifications presented here provide valuable initial insight into the increasing relevance of water-use activities in the upper Indus for the basin's upstream-downstream linkages and hydropolitics. Consistent with other studies (Vinca et al., 2020; Viviroli et al., 2020; Wijngaard et al., 2018), per capita water availability in the lower Indus was shown to decrease over the projected period under integrated climatic and socio-economic changes, while the dependency on up- 


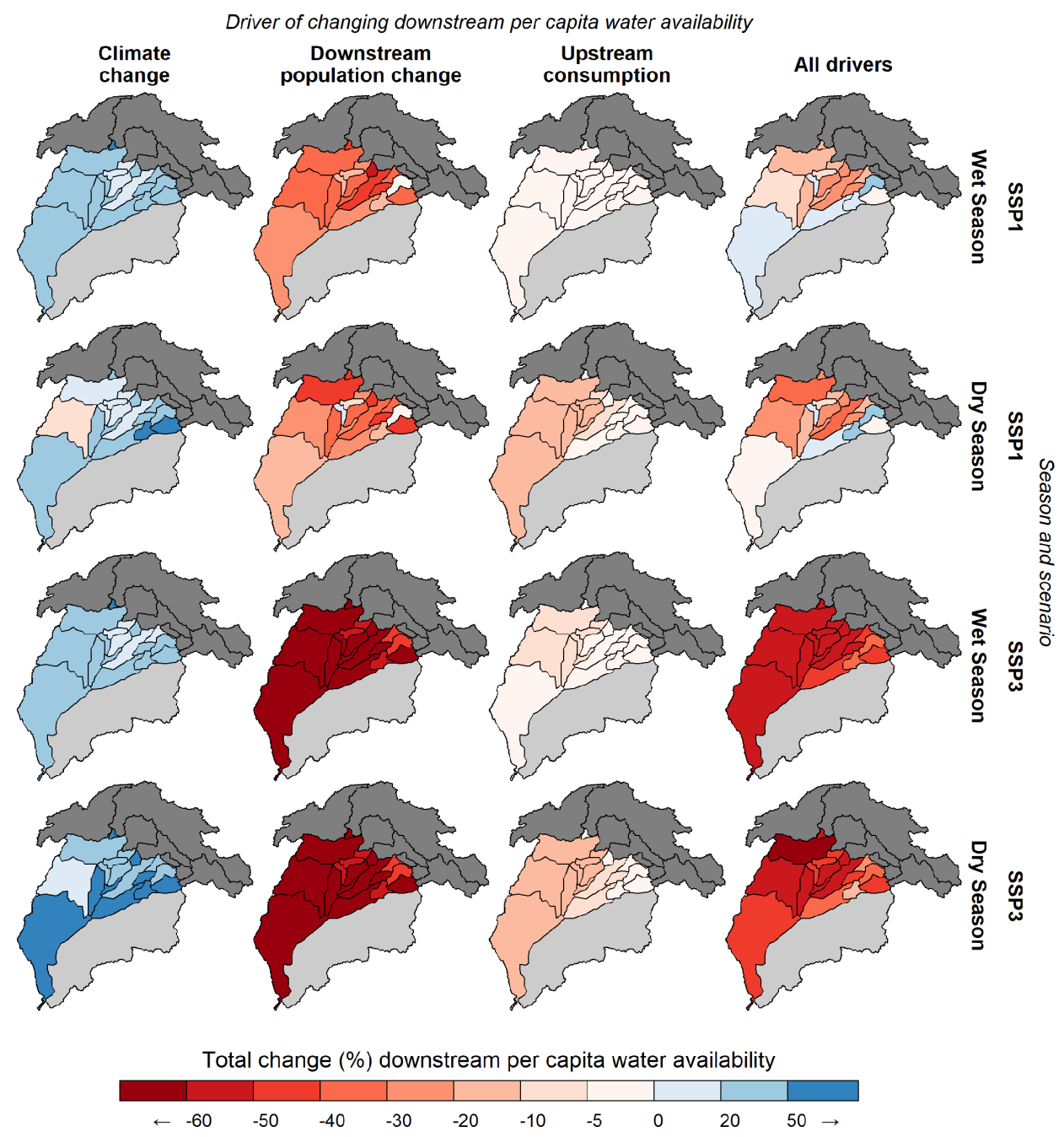

Figure 7. Isolated impact of climate change, downstream population change and upstream consumption on seasonal lower Indus water availability in the Late period (i.e. compared to the Late period situation without the effect of the respective driver). Additionally, the change in Late period water availability with all drivers considered is compared to reference period water availability.

stream water resources increases. Within this development, the reduction in average annual lower Indus water availability, which can be attributed to expanding water consumption in the upper Indus, remains limited, between $4 \%$ and $5 \%$. This is in a similar range to study outcomes by Munia et al. (2016) and Degefu et al. (2019), who found current upper Indus consumption to increase downstream water stress by respectively $2 \%$ to $4 \%$ and $1 \%$ to $5 \%$.

However, our results also demonstrate that, when using a spatio-temporally disaggregated approach, hotspot seasons and sub-basins emerge in the lower Indus where the reduction in water availability due to upstream consumption can exceed $25 \%$. Most affected hereby are the densely populated and rapidly urbanizing central Indus Plains of Pakistan, downstream of the Jhelum and Kabul sub-basins, during the dry winter season. The upstream areas and water-use activities of these sub-basins are located in the Afghani and Indian shares of the basin respectively. The disaggregation of water availability drivers additionally demonstrated that these upstream changes compound a larger decrease in downstream per capita water availability due to population growth, especially in sub-basins with major cities. This suggests that growing upstream consumption will considerably contribute to increasing transboundary water stress in the lower Indus in the dry period of the year in which pressure on water resources is already highest (Wijngaard et al., 2018). Systemic adaptive changes to the irrigation-dominated lower Indus water system, as proposed by previous studies (Immerzeel and Bierkens, 2012; Immerzeel et al., 2020; Vinca et al., 2020; Wada et al., 2019), are thus needed to ensure long-term downstream water security here. Our study highlights however that these efforts, and modelling studies in support of them, must explicitly account for changing upper Indus water use and its implications for water availability downstream. 
This study furthermore provides novel insight into the future water balance of upper Indus sub-basins. Strong population growth around the largest urban centres of the upper Indus was demonstrated to cause the Jhelum and Kabul sub-basins to become water stressed themselves by the second half of the century. During the low-flow winter season, consumptive water requirements here will consistently claim the majority of available surface water. The actual water demands required to satisfy consumptive requirements are manifold higher (Bijl et al., 2016) and can likely structurally not be met. This indicates that adaptive changes to regional water management and water-use behaviour are essential to mitigate water scarcity issues and achieve water security SDGs, not only in downstream Pakistan, but in the Indian and Afghani shares of these upstream sub-basins as well. During the wettest period of the year, over $90 \%$ of surface water remains available. A valuable adaptation avenue suggested by Amin et al. (2018) may therefore lie with modulating seasonal difference with storage dams specifically for upper Indus water provision.

However, the Kabul and Jhelum sub-basins are transboundary. Past plans to construct additional hydropower dams, with limited storage capacity, in the Indian share of the Chenab sub-basin have led to disputes over fears that this infrastructure could be used to further control the flow of vital dry season water resources to downstream Pakistan and infringe on the terms of the Indus Water Treaty (Ahmad and Iqbal, 2016). Both the increasing upstream water use projected for these sub-basins, and hydrological interventions to facilitate this use such as storage dams and diversion canals, may therefore intensify upstream-downstream water competition and aggravate existing hydropolitical tensions between riparian states (Atef et al., 2019; Gupta and Ebrahim, 2017). Transboundary water competition may further exacerbate as downstream demands in the heavily irrigated and densely populated Pakistani and Indian Punjab are also expected to increase with substantial projected population growth, particularly in the SSP3-RCP8.5 scenario (Wijngaard et al., 2018). This demand is most likely to be met with increased use of upstream water and may prompt riparian states to capitalize to even greater extent on upper Indus water resources allotted to them in the Indus Water Treaty (Zawahri and Michel, 2018).

The results of this study therefore support the claims of previous studies that the Indus Water Treaty needs to be revisited (Ahmad and Iqbal, 2016; Kalair et al., 2019; Qamar et al., 2019; Wada et al., 2019) and include the Kabul tributary, and thereby Afghanistan (Zawahri and Michel, 2018), in order to ensure equitable and sustainable future water allocation between riparian states and provide a robust platform for the development of basin-wide adaptation strategies. The role of climatic changes in this process has been at the forefront of scientific attention (Kalair et al., 2019; Qamar et al., 2019) and policy-making (Parvaiz, 2021) in recent years. However, our quantifications show that socio- economic changes may have a larger influence on future upstream-downstream linkages in the basin and the subsequent water stress experienced by its inhabitants. This suggests that any revisitation of existing treaties, like the IWT, towards improved shared water management must account for future socio-economic changes in both the upper and lower Indus Basin, alongside the role of climatic change. We specifically identified several transboundary interactions that are likely to intensify in the future and must be addressed accordingly in this process. These hotspots moreover provide targets of special consideration for transboundary cooperation, adaptation policy-making and future hydrological modelling studies in support of the integrated pursuit of the water and food security SDGs.

\section{Conclusions}

This study quantified the role of current and future water use in the upper Indus on downstream water availability for two integrated socio-economic development and climate change scenarios. The results demonstrate that growing water usage in the upper Indus Basin is a significant factor in the evolving upstream-downstream linkages of the Indus Basin. The combined consumption across the seven upper Indus subbasins is projected to increase from $6.9 \mathrm{~km}^{3} \mathrm{yr}^{-1}$ presently to $13-17 \mathrm{~km}^{3} \mathrm{yr}^{-1}$ by $2060-2080$. This will cause considerable pressure on surface water resources in the dry season. It has been demonstrated that the transboundary Kabul subbasin, shared by Afghanistan and Pakistan, and the Jhelum sub-basin, shared by India and Pakistan, in particular, will become increasingly water stressed due to rapid population growth, despite an increase in surface water availability through climate change. Water requirements during the critical winter months here may structurally exceed $50 \%$ (Jhelum) and $90 \%$ (Kabul) of surface water availability in the future and increasingly impede environmental flows from being met. Scarcely populated upstream sub-basins, such as the Satluj and Ravi sub-basins in the Indian share of the basin, instead see climate change as the dominant driver and face an overall increase in future water availability due to its impact on meltwater.

The large differences in relative upper Indus water consumption between seasons and sub-basins result in spatiotemporal impact hotspots in the lower Indus where surface water availability is reduced by over $25 \%$ compared to natural flow conditions. This amplifies a greater decrease in future downstream per capita water availability due to population growth. The negative impact of these two socioeconomic drivers outweighs the positive effects of climate change on water availability, especially under the rapid population growth of the SSP3-RCP8.5 scenario. Growing upper Indus water consumption plays a particularly substantial role in the decreasing trend of dry season water availability of the densely populated Indus Plains of the Pakistani share 
of the basin. Expanding water usage in the upper Indus may thus lead to in situ water scarcity issues in several upstream sub-basins and intensify the already considerable water stress faced in transboundary downstream areas during the dry season.

The quantified outlook on the development of upstreamdownstream linkages under various drivers provided in this study holds several insights for transboundary cooperation, long-term water management and adaptation planning in the hydropolitically complex Indus Basin. Foremost, adaptation strategies towards achieving the interlinked water and food security SDGs are required not just in the lower Indus Plains of Pakistan, but also in the Kabul and Jhelum subbasins of the upper Indus that are administered largely by Afghanistan and India. This implies that adaptation policy and revisions of shared water management practices must explicitly consider the impact of socio-economic changes on the evolution of upstream-downstream dependencies in the Indus Basin and its transboundary implications for water demand and availability throughout it. Future disaggregated modelling assessment of the future Indus Basin water system in support of these processes similarly needs to include socio-economic development in the upper Indus. Subsequent research may focus on further untangling Indus upstreamdownstream linkages by disaggregating hydrological dependencies within the lower Indus as well, and by evaluating implications "by-and-for" adaptation strategies.

$$
\begin{aligned}
& C_{r}^{\mathrm{I}}=V_{r}(t) \cdot \alpha \cdot G_{r}(t)^{b} \cdot R_{r}^{\mathrm{I}} \cdot F_{r}^{\mathrm{I}} \cdot E_{r}^{i}(t) \\
& C_{r}^{\mathrm{M}}=P_{r}(t) \cdot \frac{c}{1+e^{\left(\frac{m-\ln \left(G_{r}(t)\right)}{s}\right)}} \cdot R_{r}^{\mathrm{M}} \cdot F_{r}^{\mathrm{M}} \cdot E_{r}^{\mathrm{M}}(t)
\end{aligned}
$$

The above formulas were used to determine industrial (Eq. A1) and municipal (Eq. A2) water consumption from Bijl et al. (2016), where $C$ stands for the consumption $\left(\mathrm{m}^{3} \mathrm{yr}^{-1}\right)$ for the industrial (I) and municipal (M) sector for year $t$ and region $r$. The models first determine the structural withdrawals for a region in a year, for which $V$ is the economic driving force of total industry value added (USD per year), $P$ is the population (of that year) and $G$ is the level of economic development (expressed in USD of GDP per year). These are then multiplied by a static region factor $(R)$ that accounts for cultural factors, a static consumption fraction $(F)$ and an annual efficiency factor $(E)$. The industrial model moreover has two parameters, $\alpha$ and $b$, that were calibrated at 3.57 and -0.564 respectively. The municipal model contains two parameters, $c$ and $s$, that were calibrated at 8.575 and 0.6985 respectively. Additionally a midpoint $(m)$ was defined at $143.5\left(\mathrm{~m}^{3}\right.$ per capita per year) by Bijl et al. (2016). The economic and population data used to run these models were sourced from Smolenaars et al. (2021) and are described in the methodology. The region factors, consumption fraction and efficiency factors were sourced from Bijl et al. (2016).

\section{Appendix A}
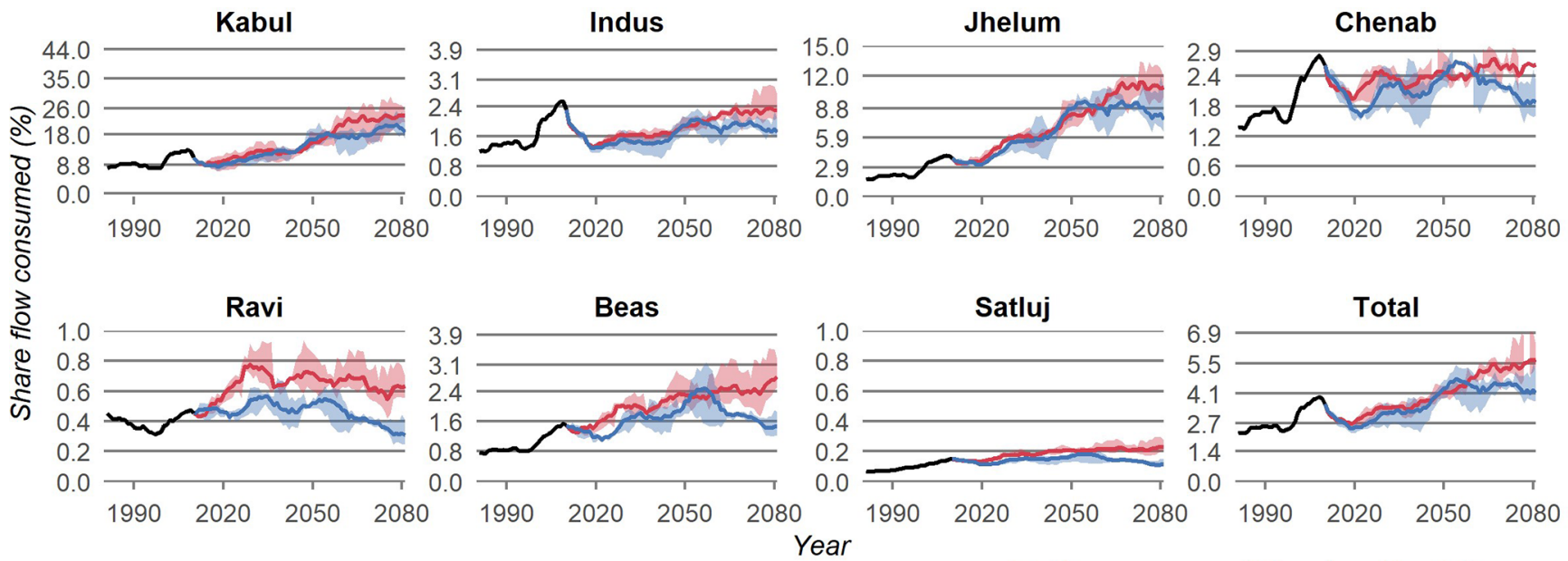

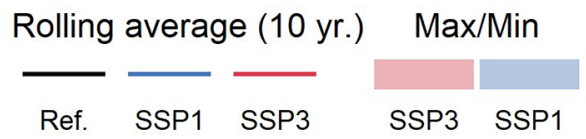

Figure A1. Share of annual discharge consumed in each sub-basin and for the total upper Indus Basin. 

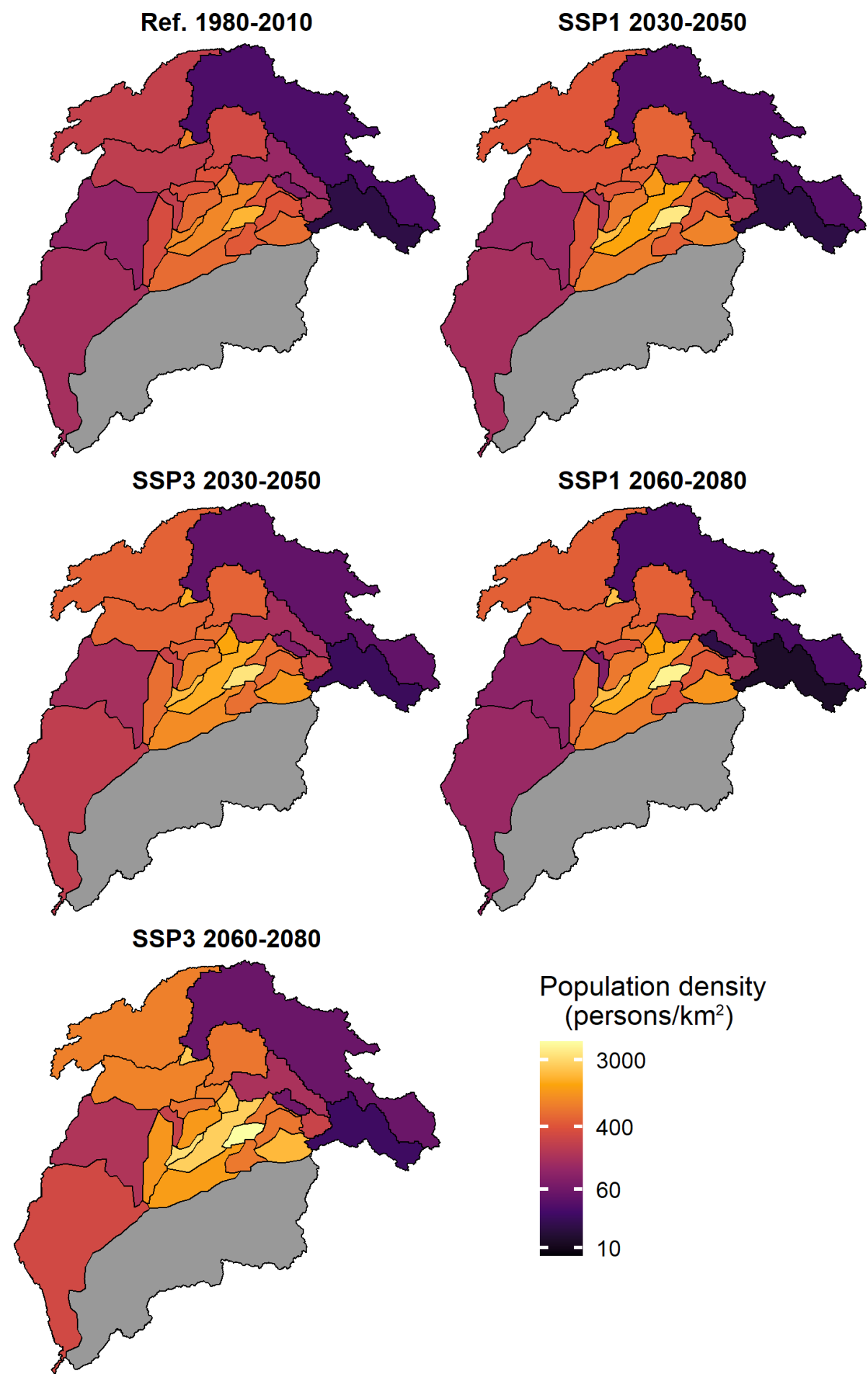

\section{Population density \\ (persons $/ \mathrm{km}^{2}$ )}

3000

400

60

10

Figure A2. Population density of each upper and lower Indus sub-basin through time and for both scenarios, as used in this study. The population projections were sourced from Smolenaars et al. (2021, under review). They were developed by spatially downscaling the national population projections of the global SSP framework using a regionalized population model that considers urbanization, internal highland-tolowland migration and proximity to infrastructure. These drivers were weighted relative to the scenario context sourced from both the global SSPs and pre-existing qualitative regional development storylines developed by Roy et al. (2019). 

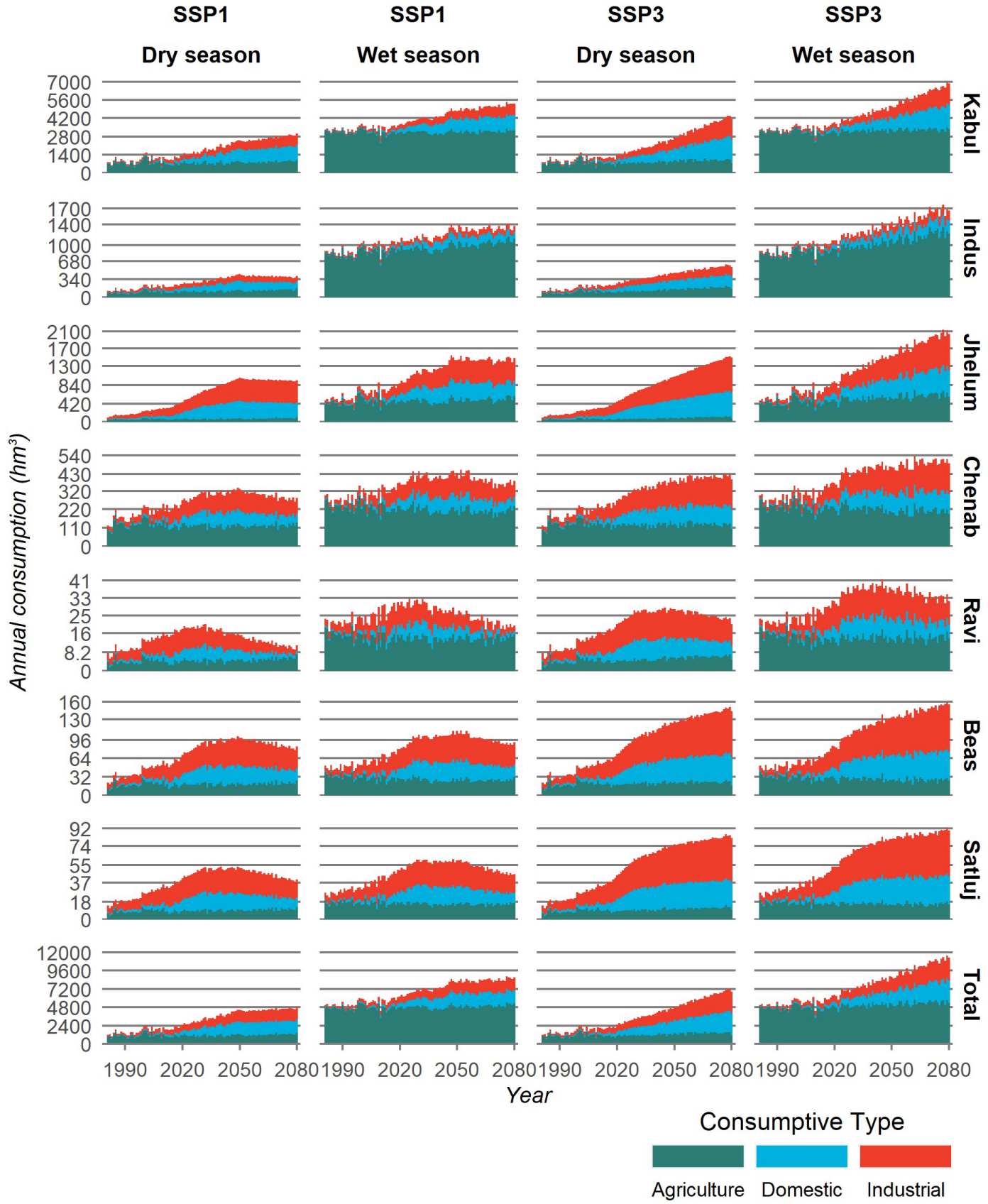

Figure A3. Domestic, industrial and agricultural water development per season and scenario. 


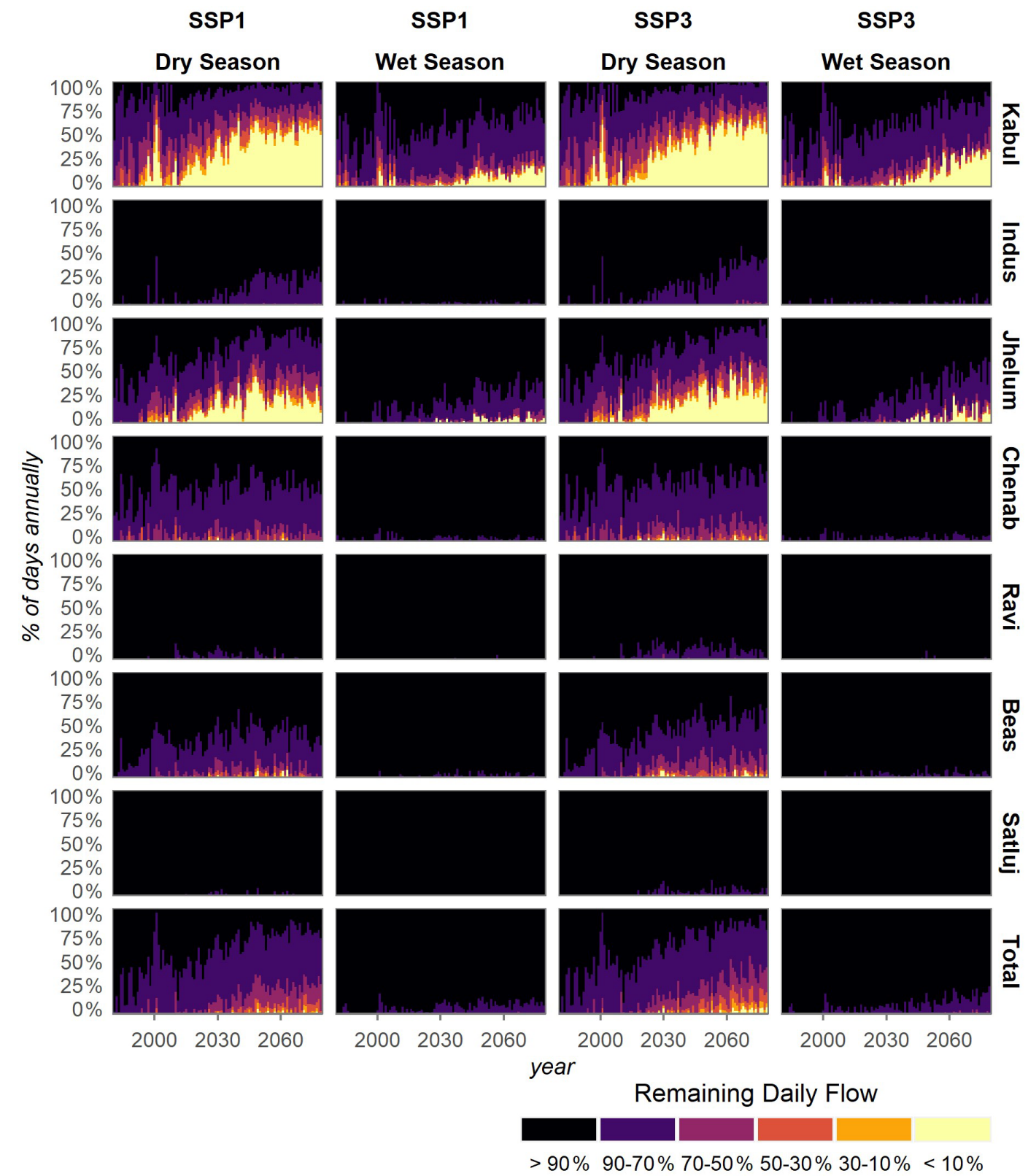

Figure A4. Development of the daily remaining flow per season and per scenario.

Code and data availability. All codes and data are available from the authors upon request.

Author contributions. WJS and HB conceptualized and designed the methodological approach of this study. WJS collected the data, performed the data analysis and wrote the original draft paper. MKJ and SD were responsible for regional validation and interpretation of model outputs. SD, AL, WI, FL, MKJ and HB reviewed and edited the final draft. FL, HB and WI supervised the procedure.
Competing interests. The contact author has declared that neither they nor their co-authors have any competing interests.

Disclaimer. Publisher's note: Copernicus Publications remains neutral with regard to jurisdictional claims in published maps and institutional affiliations. 
Special issue statement. This article is part of the special issue "Socio-hydrology and transboundary rivers". It is not associated with a conference.

Acknowledgements. The work of all authors is supported by the SustaIndus project, funded by NWO Wotro (Project W 07.30318.002), by the Interdisciplinary Research and Education Fund (INREF) of Wageningen University and Research and by Utrecht University. HB would like to acknowledge partial funding from Wageningen University and the Food Security and Valuing Water research programme supported by the Dutch Ministry of Agriculture, Nature and Food Security.

Financial support. This research has been supported by the Nederlandse Organisatie voor Wetenschappelijk Onderzoek (grant no. W 07.30318.002). Hester Biemans has partially received funding from the KB35 "Food Security and Valuing Water programme" that is supported by the Dutch Ministry of Agriculture, Nature and Food Security.

Review statement. This paper was edited by Murugesu Sivapalan and reviewed by two anonymous referees.

\section{References}

Ahmad, S. and Iqbal, J.: Transboundary impact assessment of Indian dams: a case study of Chenab River Basin in perspective of Indus Water Treaty, Water Policy, 18, 545-564, 2016.

Amin, A., Iqbal, J., Asghar, A., and Ribbe, L.: Analysis of current and future water demands in the Upper Indus Basin under IPCC climate and socio-economic scenarios using a hydro-economic WEAP model, Water, 10, 537, 2018.

Atef, S. S., Sadeqinazhad, F., Farjaad, F., and Amatya, D. M.: Water conflict management and cooperation between Afghanistan and Pakistan, J. Hydrol., 570, 875-892, 2019.

Basharat, M.: Water Management in the Indus Basin in Pakistan: Challenges and Opportunities, in: Indus River Basin, Elsevier, 375-388, https://doi.org/10.1659/mrd-journal-d11-00019.1, 2019.

Basharat, M., Sultan, S., and Malik, A.: Groundwater management in Indus Plain and integrated water resources management approach, Pakistan Water and Power Development Authority (WAPDA), Lahore, Pakistan, available at: https://www.researchgate.net/publication/283014096_ Groundwater_Management_in_Indus_Plain_and_Integrated_ Water_Resources_Management_Approach (last access: 15 February 2022), 2015.

Biemans, H., Speelman, L. H., Ludwig, F., Moors, E. J., Wiltshire, A. J., Kumar, P., Gerten, D., and Kabat, P.: Future water resources for food production in five South Asian river basins and potential for adaptation - A modeling study, Sci. Total Environ., 468, S117-S131, 2013.

Biemans, H., Siderius, C., Mishra, A., and Ahmad, B.: Crop-specific seasonal estimates of irrigation-water demand in South Asia, Hydrol. Earth Syst. Sci., 20, 1971-1982, https://doi.org/10.5194/hess-20-1971-2016, 2016.

Biemans, H., Siderius, C., Lutz, A. F., Nepal, S., Ahmad, B., Hassan, T., von Bloh, W., Wijngaard, R. R., Wester, P., Shrestha, A. B., and Immerzeel, W. W.: Importance of snow and glacier meltwater for agriculture on the Indo-Gangetic Plain, Nature Sustainability, 2, 594-601, 2019.

Bijl, D. L., Bogaart, P. W., Kram, T., de Vries, B. J., and van Vuuren, D. P.: Long-term water demand for electricity, industry and households, Environ. Sci. Policy, 55, 75-86, 2016.

Bondeau, A., Smith, P. C., Zaehle, S., Schaphoff, S., Lucht, W., Cramer, W., Gerten, D., Lotze-Campen, H., Müller, C., Reichstein, M., and Smith, B.: Modelling the role of agriculture for the 20th century global terrestrial carbon balance, Glob. Change Biol., 13, 679-706, 2007.

Cheema, M., Immerzeel, W., and Bastiaanssen, W.: Spatial quantification of groundwater abstraction in the irrigated Indus basin, Groundwater, 52, 25-36, 2014.

Degefu, D. M., Liao, Z., He, W., Yuan, L., An, M., Zhang, Z., and Xia, W.: The Impact of Upstream Sub-basins' Water Use on Middle Stream and Downstream Sub-basins' Water Security at Country-Basin Unit Spatial Scale and Monthly Temporal Resolution, Int. J. Env. Res. Pub. He., 16, 450, 2019.

Dellink, R., Chateau, J., Lanzi, E., and Magné, B.: Long-term economic growth projections in the Shared Socioeconomic Pathways. Global Environ. Chang., 42, 200-214, 2017.

Falkenmark, M., Lundqvist, J., and Widstrand, C.: Macro-scale water scarcity requires micro-scale approaches: Aspects of vulnerability in semi-arid development, Paper presented at the Natural resources forum, Blackwell Publishing, Ltd Oxford, UK, https://doi.org/10.1111/j.1477-8947.1989.tb00348.x, 1989.

Flörke, M., Schneider, C., and McDonald, R. I.: Water competition between cities and agriculture driven by climate change and urban growth, Nature Sustainability, 1, 51-58, 2018.

Gerten, D., Heinke, J., Hoff, H., Biemans, H., Fader, M., and Waha, K.: Global water availability and requirements for future food production, J. Hydrometeorol., 12, 885-899, 2011.

Gupta, J. and Ebrahim, Z.: Win some, lose some, Indus Waters Treaty continues, available at: https: //www.thethirdpole.net/en/regional-cooperation/ win-some-lose-some-indus-waters-treaty-continues/

(last access: 11 February 2022), 2017.

Hanasaki, N., Yoshikawa, S., Pokhrel, Y., and Kanae, S.: A quantitative investigation of the thresholds for two conventional water scarcity indicators using a state-of-the-art global hydrological model with human activities, Water Resour. Res., 54, 8279-8294, 2018.

Hassan, D., Burian, S. J., Bano, R., Ahmed, W., Arfan, M., Rais, M. N., Rafique, A., and Ansari, K.: An assessment of the Pakistan water apportionment accord of 1991, Resources, 8, 120, https://doi.org/10.3390/resources8030120, 2019.

Immerzeel, W. and Bierkens, M.: Asia's water balance, Nature Geosci., 5, 841, 2012.

Immerzeel, W. W., Lutz, A. F., Andrade, M., Bahl, A., Biemans, H., Bolch, T., Hyde, S., Brumby, S., Davies, B. J., Elmore, A. C., Emmer, A., Feng, M., Fernández, A., Haritashya, U., Kargel, J. S., Koppes, M., Kraaijenbrink, P. D. A., Kulkarni, A. V., Mayewski, P. A., Nepal, S., Pacheco, P., Painter, T. H., Pellicciotti, F., Rajaram, H., Rupper, S., Sinisalo, A., Shrestha, A. B., 
Viviroli, D., Wada, Y., Xiao, C., Yao, T., and Baillie, J. E. M.: Importance and vulnerability of the world's water towers, Nature, 577, 364-369, https://doi.org/10.1038/s41586-019-1822-y, 2020.

Jägermeyr, J., Pastor, A., Biemans, H., and Gerten, D.: Reconciling irrigated food production with environmental flows for Sustainable Development Goals implementation, Nat. Commun., 8, 15900, 2017.

Johnston, R. and Smakhtin, V.: Hydrological modeling of large river basins: how much is enough?, Water Resour. Manag., 28, 26952730, 2014.

Kalair, A. R., Abas, N., Hasan, Q. U., Kalair, E., Kalair, A., and Khan, N.: Water, energy and food nexus of Indus Water Treaty: Water governance, Water-Energy Nexus, 2, 10-24, 2019.

Karimi, P., Bastiaanssen, W. G. M., Molden, D., and Cheema, M. J. M.: Basin-wide water accounting based on remote sensing data: an application for the Indus Basin, Hydrol. Earth Syst. Sci., 17, 2473-2486, https://doi.org/10.5194/hess-17-2473-2013, 2013.

Khan, A. J., Koch, M., and Tahir, A. A.: Impacts of Climate Change on the Water Availability, Seasonality and Extremes in the Upper Indus Basin (UIB), Sustainability, 12, 1283, 2020.

Klein Goldewijk, K., Beusen, A., Van Drecht, G., and De Vos, M.: The HYDE 3.1 spatially explicit database of human-induced global land-use change over the past 12000 years, Global Ecol. Biogeogr., 20, 73-86, 2011.

Laghari, A. N., Vanham, D., and Rauch, W.: The Indus basin in the framework of current and future water resources management, Hydrol. Earth Syst. Sci., 16, 1063-1083, https://doi.org/10.5194/hess-16-1063-2012, 2012.

Lehner, B., Verdin, K., and Jarvis, A.: HydroSHEDS technical documentation, World Wildlife Fund US, Washington, DC, 1-27, available at: https://www.hydrosheds.org/ images/inpages/HydroSHEDS_TechDoc_v1_2.pdf (last access: 15 February 2022), 2006.

Lutz, A., Immerzeel, W., Shrestha, A., and Bierkens, M.: Consistent increase in High Asia's runoff due to increasing glacier melt and precipitation, Nat. Clim. Change, 4, 587, 2014.

Lutz, A. F., Immerzeel, W., Kraaijenbrink, P., Shrestha, A. B., and Bierkens, M. F.: Climate change impacts on the upper Indus hydrology: Sources, shifts and extremes, PloS one, 11, e0165630, https://doi.org/10.1371/journal.pone.0165630, 2016a.

Lutz, A. F., ter Maat, H. W., Biemans, H., Shrestha, A. B., Wester, P., and Immerzeel, W. W.: Selecting representative climate models for climate change impact studies: an advanced envelopebased selection approach, Int. J. Climatol., 36, 3988-4005, 2016b.

Lutz, A. F., ter Maat, H. W., Wijngaard, R. R., Biemans, H., Syed, A., Shrestha, A. B., Wester, P., and Immerzeel, W. W.: South Asian river basins in a $1.5^{\circ} \mathrm{C}$ warmer world, Reg. Environ. Change, 19, 833-847, 2019.

Mack, T. J., Chornack, M. P., and Taher, M. R.: Groundwater-level trends and implications for sustainable water use in the Kabul Basin, Afghanistan, Environment Systems and Decisions, 33, 457-467, 2013.

Mehboob, M. S. and Kim, Y.: Effect of climate and socioeconomic changes on future surface water availability from mountainous water sources in Pakistan's Upper Indus Basin, Sci. Total Environ., 769, 144820, https://doi.org/10.1016/j.scitotenv.2020.144820, 2021.
Miner, M., Patankar, G., Gamkhar, S., and Eaton, D. J.: Water sharing between India and Pakistan: a critical evaluation of the Indus Water Treaty, Water Int., 34, 204-216, 2009.

Momblanch, A., Papadimitriou, L., Jain, S. K., Kulkarni, A., Ojha, C. S., Adeloye, A. J., and Holman, I. P.: Untangling the waterfood-energy-environment nexus for global change adaptation in a complex Himalayan water resource system, Sci. Total Environ., 655, 35-47, 2019.

Munia, H., Guillaume, J. H. A., Mirumachi, N., Porkka, M., Wada, Y., and Kummu, M.: Water stress in global transboundary river basins: significance of upstream water use on downstream stress, Environ. Res. Lett., 11, 014002, https://doi.org/10.1088/17489326/11/1/014002, 2016.

Munia, H. A., Guillaume, J. H. A., Mirumachi, N., Wada, Y., and Kummu, M.: How downstream sub-basins depend on upstream inflows to avoid scarcity: typology and global analysis of transboundary rivers, Hydrol. Earth Syst. Sci., 22, 2795-2809, https://doi.org/10.5194/hess-22-2795-2018, 2018.

Munia, H. A., Guillaume, J. H., Wada, Y., Veldkamp, T., Virkki, V., and Kummu, M.: Future transboundary water stress and its drivers under climate change: A global study, Earths Future, 8, e2019EF001321, https://doi.org/10.1029/2019EF001321, 2020.

O’Neill, B. C., Kriegler, E., Riahi, K., Ebi, K. L., Hallegatte, S., Carter, T. R., Mathur, R., and van Vuuren, D. P.: A new scenario framework for climate change research: the concept of shared socioeconomic pathways, Climatic Change, 122, 387-400, 2014.

Parvaiz, A.: India, Pakistan cross-border water treaty needs climate change revision, Nature News, 1755-3180, available at: https://www.nature.com/articles/d44151-021-00036-8 (last access: 16 February 2022), 2021.

Pastor, A. V., Palazzo, A., Havlik, P., Biemans, H., Wada, Y., Obersteiner, M., Kabat, P., and Ludwig, F.: The global nexus of foodtrade-water sustaining environmental flows by 2050 , Nature Sustainability, 2, 499-507, 2019.

Pastor, A. V., Ludwig, F., Biemans, H., Hoff, H., and Kabat, P.: Accounting for environmental flow requirements in global water assessments, Hydrol. Earth Syst. Sci., 18, 5041-5059, https://doi.org/10.5194/hess-18-5041-2014, 2014.

Portmann, F. T., Siebert, S., and Döll, P.: MIRCA2000-Global monthly irrigated and rainfed crop areas around the year 2000: A new high-resolution data set for agricultural and hydrological modeling, Global Biogeochem. Cy., 24, GB1011, https://doi.org/10.1029/2008GB003435, 2010.

Qamar, M. U., Azmat, M., and Claps, P.: Pitfalls in transboundary Indus Water Treaty: a perspective to prevent unattended threats to the global security, npj Clean Water, 2, 1-9, 2019.

Qureshi, A. S., McCornick, P. G., Sarwar, A., and Sharma, B. R.: Challenges and prospects of sustainable groundwater management in the Indus Basin, Pakistan, Water Resour. Manag., 24, 1551-1569, 2010.

Rajbhandari, R., Shrestha, A., Kulkarni, A., Patwardhan, S., and Bajracharya, S.: Projected changes in climate over the Indus river basin using a high resolution regional climate model (PRECIS), Clim. Dynam., 44, 339-357, 2015.

Rangecroft, S., Van Loon, A. F., Maureira, H., Verbist, K., and Hannah, D. M.: An observation-based method to quantify the human influence on hydrological drought: upstream-downstream comparison, Hydrolog. Sci. J., 64, 276-287, 2019. 
Rasul, G.: Food, water, and energy security in South Asia: A nexus perspective from the Hindu Kush Himalayan region, Environ. Sci. Policy, 39, 35-48, 2014.

Rasul, G.: Managing the food, water, and energy nexus for achieving the Sustainable Development Goals in South Asia, Environmental Development, 18, 14-25, 2016.

Reggiani, P. and Rientjes, T.: A reflection on the long-term water balance of the Upper Indus Basin, Hydrol. Res., 46, 446-462, 2015.

Richey, A. S., Thomas, B. F., Lo, M. H., Reager, J. T., Famiglietti, J. S., Voss, K., Swenson, S., and Rodell, M.: Quantifying renewable groundwater stress with GRACE, Water Resour. Res., 51, 52175238, 2015.

Rost, S., Gerten, D., Bondeau, A., Lucht, W., Rohwer, J., and Schaphoff, S.: Agricultural green and blue water consumption and its influence on the global water system, Water Resour. Res., 44, W09405, https://doi.org/10.1029/2007WR006331, 2008.

Roy, J., Moors, E., Murthy, M. S. R., Prabhakar, S. V. R. K., Khattak, B. N., Shi, P., Huggel, C., and Chitale, V.: Exploring Futures of the Hindu Kush Himalaya: Scenarios and Pathways, in: The Hindu Kush Himalaya Assessment, Springer, 99-125, https://doi.org/10.1007/978-3-319-92288-1, 2019.

Salam, M., Cheema, M. J. M., Zhang, W., Hussain, S., Khan, A., Bilal, M., Arshad, A., Ali, S., and Zaman, M. A.: Groundwater storage change estimation using grace satellite data in Indus Basin, Big Data in Water Resources Engineering (BDWRE), 1, 13-18, 2020.

Stehfest, E., van Vuuren, D., Bouwman, L., and Kram, T.: Integrated assessment of global environmental change with IMAGE 3.0: Model description and policy applications, Netherlands Environmental Assessment Agency (PBL), ISBN 978-94-91506-71-0, 2014.

Smolenaars, W. J., Lutz, A. F., Biemans, H., Dhaubanjar, S., Immerzeel, W. W., and Ludwig, F.: From narratives to numbers; Spatial downscaling and quantification of future water, food and energy security requirements in the Indus basin, Futures, 133, 102831, https://doi.org/10.1016/j.futures.2021.102831, 2021.

Van Loon, A. F., Gleeson, T., Clark, J., Van Dijk, A. I., Stahl, K., Hannaford, J., Di Baldassarre, G., Teuling, A. J., Tallaksen, L. M., Uijlenhoet, R., and Hannah, D. M.: Drought in the Anthropocene, Nat. Geosci., 9, 89, 2016.

van Vuuren, D. P., Kriegler, E., O’Neill, B. C., Ebi, K. L., Riahi, K., Carter, T. R., Edmonds, J., Hallegatte, S., Kram, T., Mathur, R., and Winkler, H.: A new scenario framework for Climate Change Research: scenario matrix architecture, Climatic Change, 122, 373-386, https://doi.org/10.1007/s10584-013-0906-1, 2014.

Vinca, A., Parkinson, S., Riahi, K., Byers, E., Siddiqi, A., Muhammad, A., Ilyas, A., Yogeswaran, N., Willaarts, B., Magnuszewski, P., and Awais, M.: Transboundary cooperation a potential route to sustainable development in the Indus basin, Nature Sustainability, 4, 1-9, 2020.
Viviroli, D., Kummu, M., Meybeck, M., Kallio, M., and Wada, Y.: Increasing dependence of lowland populations on mountain water resources, Nature Sustainability, 3, 917-928, 2020.

Wada, Y., Van Beek, L., Viviroli, D., Dürr, H. H., Weingartner, R., and Bierkens, M. F.: Global monthly water stress: 2. Water demand and severity of water stress, Water Resour. Res., 47, W07518, https://doi.org/10.1029/2010WR009792, 2011.

Wada, Y., Vinca, A., Parkinson, S., Willaarts, B. A., Magnuszewski, P., Mochizuki, J., Mayor, B., Wang, Y., Burek, P., Byers, E., and Riahi, K.: Co-designing Indus Water-Energy-Land Futures, One Earth, 1, 185-194, 2019.

Wescoat Jr, J. L., Siddiqi, A., and Muhammad, A.: Socio-hydrology of channel flows in complex river basins: Rivers, canals, and distributaries in Punjab, Pakistan, Water Resour. Res., 54, 464-479, 2018.

Wijngaard, R. R., Lutz, A. F., Nepal, S., Khanal, S., Pradhananga, S., Shrestha, A. B., and Immerzeel, W. W.: Future changes in hydro-climatic extremes in the Upper Indus, Ganges, and Brahmaputra River basins, PloS one, 12, e0190224, https://doi.org/10.1371/journal.pone.0190224, 2017.

Wijngaard, R. R., Biemans, H., Lutz, A. F., Shrestha, A. B., Wester, P., and Immerzeel, W. W.: Climate change vs. socio-economic development: understanding the future South Asian water gap, Hydrol. Earth Syst. Sci., 22, 6297-6321, https://doi.org/10.5194/hess-22-6297-2018, 2018.

Wolf, A. T.: Shared waters: Conflict and cooperation, Annu. Rev. Env. Resour., 32, 241-269, 2007.

Yang, Y. E., Ringler, C., Brown, C., and Mondal, M. A. H.: Modeling the Agricultural Water-Energy-Food Nexus in the Indus River Basin, Pakistan, J. Water Res. Pl., 142, 04016062, https://doi.org/10.1061/(ASCE)WR.1943-5452.0000710, 2016.

Yillia, P. T.: Water-Energy-Food nexus: framing the opportunities, challenges and synergies for implementing the SDGs, Österreichische Wasser-und Abfallwirtschaft, 68, 86-98, 2016.

Yoon, T., Rhodes, C., and Shah, F. A.: Upstream water resource management to address downstream pollution concerns: A policy framework with application to the Nakdong River basin in South Korea, Water Resour. Res., 51, 787-805, 2015.

Zawahri, N. and Michel, D.: Assessing the Indus Waters Treaty from a comparative perspective, Water Int., 43, 696-712, 2018.

Zhou, X., Yang, Y., Sheng, Z., and Zhang, Y.: Reconstructed natural runoff helps to quantify the relationship between upstream water use and downstream water scarcity in China's river basins, Hydrol. Earth Syst. Sci., 23, 2491-2505, https://doi.org/10.5194/hess-23-2491-2019, 2019. 